\title{
Pathways to inflated responsibility beliefs in adolescent obsessive-compulsive disorder: a preliminary investigation
}

Article

Supplemental Material

Text contains unpublished appendicies

Lawrence, P. J. P. and Williams, T. I. (2011) Pathways to inflated responsibility beliefs in adolescent obsessivecompulsive disorder: a preliminary investigation. Behavioural and Cognitive Psychotherapy, 39 (2). pp. 229-234. ISSN 13524658 doi: https://doi.org/10.1017/S1352465810000810 Available at https://centaur.reading.ac.uk/18191/

It is advisable to refer to the publisher's version if you intend to cite from the work. See Guidance on citing.

To link to this article DOI: http://dx.doi.org/10.1017/S1352465810000810

Publisher: Cambridge University Press

All outputs in CentAUR are protected by Intellectual Property Rights law, including copyright law. Copyright and IPR is retained by the creators or other copyright holders. Terms and conditions for use of this material are defined in the End User Agreement.

www.reading.ac.uk/centaur 
Central Archive at the University of Reading

Reading's research outputs online 




Pathways to Inflated Responsibility Beliefs in Adolescent Obsessive-Compulsive Disorder: A Preliminary Investigation

\begin{tabular}{|r|l|}
\hline Journal: & Behavioural and Cognitive Psychotherapy \\
\hline Manuscript ID: & BCP-00381-10.R1 \\
\hline Manuscript Type: & Main \\
\hline Keywords: & $\begin{array}{l}\text { obsessive-compulsive disorder, OCD, development, inflated } \\
\text { responsibility }\end{array}$ \\
\hline
\end{tabular}

\section{s scholaroNE" \\ Manuscript Central}


Title:

Pathways to Inflated Responsibility Beliefs in Adolescent Obsessive-Compulsive

Disorder: A Preliminary Investigation

Running Head:

OCD: Pathways to inflated responsibility 


\begin{abstract}
Background: An inflated sense of responsibility is characteristic of obsessive-compulsive disorder (OCD). No previous studies have investigated its origins. Five potential pathways to inflated responsibility beliefs have been proposed; these are tested in this study. Method: A novel measure, the Origins Questionnaire for Adolescents (OQA), was developed to assess experiences on these five pathways. Reliability of the OQA was investigated. The experiences on the five pathways to inflated responsibility beliefs of sixteen adolescents with a history of OCD were compared to sixteen adolescents with no history of OCD. Parents also reported on adolescents' experiences on the five pathways. Results: Inter-rater reliability was high. The internal consistency of the subscales were only partly satisfactory. The groups differed on one pathway; the clinical group reported a higher sense of responsibility for significant incidents with a negative outcome prior to onset of OCD. Conclusions: An inflated sense of responsibility, in combination with the occurrence of specific incidents, might act as a vulnerability factor for development of OCD. Future research should consider how to measure the subtle effects of experiences of responsibility over the course of development.
\end{abstract}

KEYWORDS

Obsessive-compulsive, OCD, development, inflated responsibility 


\section{INTRODUCTION}

Obsessive-Compulsive Disorder (OCD) is diagnosed in approximately $0.25 \%$ of 5 to 15 year olds in the United Kingdom (Heyman, Fombonne, Simmons, Ford, Meltzer et al., 2003), and between 0.1 and $4 \%$ of children and adolescents under 18 years in other countries (Douglass, Moffitt, Dar, McGee \& Silva, 1995; Flament, Whitaker, Rappoport, Davies, Berg, et al., 1988; Lewinsohn, Hops, Roberts, Seeley, \& Andrews, 1993). Prevalence has been found to rise exponentially with age (Heyman et al., 2003). The disorder can have severe effects on children's social, academic and family functioning (Piacentini, Bergman, Keller \& McCracken, 2003).

The most researched theories of OCD are based on cognitive behavioural formulations and focus on the maintenance of the disorder (Shafran, Thordarson \& Rachman, 1996; Wells, 1997). Perhaps the most supported cognitive model is the inflated responsibility hypothesis (Salkovskis $1985 ; 1989)$. The hypothesis states that the majority of people experience intrusive thoughts (Salkovskis \& Harrison, 1984; Allsopp \& Williams, 1996), and that most people routinely dismiss them as meaningless. Some people, however, interpret these intrusive thoughts via a schema of inflated responsibility. Via this schema, a person experiences a sense of personal responsibility for some potential negative outcome for self or other. Their response is to carry out behaviours aimed to reduce their perceived personal responsibility for potential harm to self or others; these behaviours can be conceptualized as compulsions.

There is growing evidence to support an association between inflated responsibility and OCD symptoms in children and adolescents. Clinical samples of children and adolescents with OCD show significantly higher levels of inflated responsibility appraisals than a non-clinical sample of young people aged $7-11$ years (Barrett \& Healy, 2003) and young people aged 11 18 years with other anxiety disorders (Libby, Reynolds, Derisley, \& Clark, 2004). Williams, Salkovskis, Forrester and Allsopp (2002), reporting on cognitive behavioural therapy for OCD in 
6 adolescents aged $12-17$ years, note that obsessive-compulsive symptoms changed at the same time as responsibility appraisals during treatment. In an experimental design, Reeves (2006) reported that in a sample of 81 9-12 year olds, following manipulation of perceived responsibility, those in the high responsibility group demonstrated significantly more checking behaviours than those in the low responsibility group. There is, however, some contrary evidence. Barrett and Healy-Farrell (2003), in an experimental manipulation of responsibility with a clinical sample of 43 7- 17 year olds with OCD, reported that although the high responsibility group experienced greater responsibility (that is, the experimental manipulation was successful), they did not report increased levels of distress, probability of harm or more avoidant or ritualizing behaviour.

Overall, although a relatively large body of evidence supports Salkovskis' (1985) model in children and adolescents, little research has investigated what might give rise to an inflated sense of responsibility in people with OCD. Clinically experience suggests that both adolescents and adults ask about how their tendency to experience an inflated sense of responsibility might arise. Additionally an understanding of the development of inflated responsibility cognitions might enable the development of prevention methods.

Salkovskis, Shafran, Rachman and Freeston (1999) recognize that the origin and development of inflated responsibility beliefs involve complex, subtle and interacting mechanisms, and proposed a set of five pathways which could explain their development. In accordance with the general cognitive theory of psychopathology (Beck, 1976), inflated responsibility attitudes are proposed to have their root(s) in childhood, with continued socialization occurring during development. The five pathways proposed by Salkovskis et al. (1999) are as follows:

1 A broad and heightened sense of responsibility develops early in life, which is encouraged by significant figures. This might occur in the domestic environment, where a child is required by their parent(s) to carry out important tasks or chores, typically carried out by 
adults. Responsibility for negative occurrences being placed on a child by their parents or other important adults would also be included in this pathway. Salkovskis et al. (1999) propose that these experiences, which can lead to a high sense of responsibility, might be translated into conscientiousness and a keen sense of social duty.

2 Rigid codes of conduct. Salkovskis and colleagues recognize the similarity of this pathway to 1. It differs, however, in that it is limited to codes of conduct, which a person feels a sense of responsibility to follow. It is proposed that such a set of codes might be 'set' within the family context, or by an educational establishment characterized by high moral standards.

\section{Being shielded from responsibility during development or being treated as incompetent} to cope with responsibility. A young person in a family with high levels of anxiety might be likely to experience the effects of this pathway. Responsibility is explicitly or implicitly withheld from the child. For example, parents or other significant figures convey to their child a sense that danger might not be far away, and that it is better to be safe than sorry. Then, when some negative event does occur, the child is criticized for not having taken appropriate precautions to prevent that outcome. The child with experiences on this pathway might have a sense that they are not up to life's challenges, that they are too delicate.

4 A specific incident, or series of incidents, in which one's actions or inactions contribute to some negative outcome for self or other(s). This pathway is 'travelled' in a much shorter time than the first three proposed, and can also occur later in life. In this case, a sense of heightened responsibility would follow a critical incident where a person believes that a negative outcome occurred because of something they did or failed to do. Salkovskis et al. (1999) state that it could also arise after a 'near miss' incident, where a person believes that lack of the negative occurrence was due only to some chance set of circumstances.

\section{A specific incident in which one's thoughts or actions are incorrectly considered to} have led to some negative outcome for self or other(s). This pathway is characterized by misinterpretation of coincidentally linked events, specifically one's own actions or thoughts and 
a negative outcome for oneself or another person, as being causally related. An example would be to wish ill of someone, and to discover that some ill had befallen that person. Salkovskis et al. (1999) recognize that people whose cognitive style includes thought action fusion (TAF) might be more likely to develop an inflated sense of responsibility via this pathway, but that TAF it is not the sole route.

Salkovskis et al. (1999) suggest that to establish evidence regarding the hypothesised pathways to inflated responsibility, data could be collected from people who have experiences of OCD. However, at the time of preparation of this project, there was no validated measure available to gather information regarding the development of inflated responsibility beliefs. A novel measure, the Origins Questionnaire for Adolescents (OQA), was therefore developed specifically for this study to investigate adolescents' experiences of responsibility and to test the existence of the proposed pathways to inflated responsibility in OCD. Figure 1 shows how the subscales of the OQA correspond with the proposed pathways to responsibility.

\section{INSERT FIGURE 1 ABOUT HERE}

Pathways 1 and 3 are concerned with experiences of too much or too little responsibility. Subscales 1) and 3) of the OQA correspond to experiences on these pathways. In addition, a further subscale is included on the OQA, subscale 5), which relates to pathways 1 and 3 . This is because, for some given experiences (for example, being allowed to go out from home alone), whilst one individual can report experiences that would be in keeping with pathway 1 (that is, a very young age), another individual can report experiences that would be in keeping with pathway 3 (a much older age). Hence, responses on subscale 5) can provide additional information regarding pathways 1 and 3 .

Pathway 2 corresponds directly with subscale 2 ). 
Pathways 4 and 5 concern a sense of responsibility for a specific incident with a negative outcome for oneself or another. In terms of gathering information regarding specific incidents, it is not possible to be sure from a participant's report if they were actually responsible for the negative outcome, or incorrectly perceived themselves to be responsible; that is, if their experience is on pathway 4 or 5 . Therefore these two pathways are operationalized as a single subscale on the OQA, subscale 4).

The OQA is a novel measure, designed specifically for this investigation. A preliminary investigation of the validity and reliability of the OQA was therefore conducted.

In addition to gathering information from adolescents with OCD, information was gathered from parents about adolescents' experiences of responsibility during development, and their own parenting style. Chambless, Gillis, Tran and Steketee (1996) reported that adults with OCD retrospectively reported that their parents were overprotective. Barrett, Shortt and Healy (2002) reported that parents of children with OCD provided significantly fewer reinforcing responses to their child's displays of independent behaviour, and were less confident of their child's abilities than parents of children with other clinical disorders or no clinical disorder. These reported differences are in keeping with pathway 3 - being shielded from responsibility.

It is hypothesised that a group with OCD will report more experiences consistent with pathways 1 and 3, that is, on OQA subscales 1), 3) and 5), than a non-clinical group. Regarding pathway 2, it is hypothesized that an OCD group will report more experiences of rigid codes of conduct on OQA subscale 2) than a non-clinical group. Regarding pathways 4 and 5 , it is hypothesised that an OCD group will report a greater sense of responsibility than a non-clinical group for significant events with a negative outcome for themselves or another on OQA subscale 4).

\section{Research Questions}

Do adolescents with a history of OCD have different experiences of responsibility during development than adolescents without a history of OCD? 
Specifically, do adolescents with a history of OCD and their parents report more significant experiences on OQA subscales:

1) a broad sense of responsibility encouraged by significant others;

2) rigid codes of conduct;

3) being shielded from responsibility; and

4) perceptions of responsibility for specific incidents with some negative outcome for self or other?

On OQA subscale 5), do adolescents with a history of OCD report experiences of specific tasks during development that are polarized to extremes of a broad sense of responsibility and / or being shielded from responsibility? 


\section{METHODS}

\section{Design:}

This was a cross-sectional interview and questionnaire study. The hypothesised between groups differences under investigation relate to experiences of responsibility during development, that is, a possible vulnerability factor for the development of OCD. For this study, therefore, an ideal clinical group would be similar to a non-clinical group in terms of current OCD symptomatology. This would ensure that, where differences were found in terms of responsibility during development, they would not be due to a halo effect from current OCD symptoms, but could represent a vulnerability factor for the development of OCD. Therefore, inclusion criteria for the clinical group included having received treatment for OCD, which would make recovery from OCD more likely and current OCD symptomatology more similar to a nonclinical group.

All adolescent participants completed the same set of measures with the difference that the non-clinical group completed a non-clinical version of the 'Origins Questionnaire'. Similarly, parents of all adolescent participants completed the same set of measures, with the parents of the non-clinical adolescents completing the non-clinical version of the 'Independent Living Questionnaire'. 


\section{Procedure:}

\section{Participants}

Participants, aged 14 -21 years, were recruited for one of two groups, clinical or non-clinical. Inclusion criteria for the clinical group were a history of a primary diagnosis of obsessivecompulsive disorder, having received treatment for their OCD and English as a first language. The exclusion criteria were a Statement of Special Educational Need, a diagnosis of Autism Spectrum Disorder (ASD), and a diagnosis of psychosis. Inclusion criterion for the non-clinical group was English as a first language. Exclusion criteria for the non-clinical group were a history of OCD, a Statement of Special Educational Need, a diagnosis of ASD and a diagnosis of psychosis.

\section{Recruitment}

The clinical participants were identified by Child and Adolescent Mental Health Services (CAMHS) clinicians as those who had received treatment for a primary diagnosis of OCD. Nonclinical participants were recruited from state secondary schools in Oxfordshire and Berkshire.

\section{Measures:}

\section{Child Completed Questionnaire Measures}

\section{Child Obsessive-Compulsive Inventory}

The Child Obsessive-Compulsive Inventory (Child OCI) (Salkovskis \& Williams, 2004a; Waite \& Williams, 2009 - PLEASE SEE ADDITIONAL DOCUMENT) is an adaptation of the ObsessiveCompulsive Inventory (OCl) (Foa, Kozak, Salkovskis, Coles \& Amir, 1998). It was made age appropriate for children by simplification of language and shortening of sentences. The Child $\mathrm{OCl}$ gathers information on distress, but not severity. It is a self-report questionnaire, comprising 42 items divided into 7 subscales (Washing, Checking, Doubting, Ordering, Obsessing, 
Hoarding and Mental Neutralizing). Each item is rated on a Likert scale $(0-4)$. The Child OCI has not been validated, but initial normative data give a mean score in a non-clinical sample of 32.44 (Griffen, 2000).

\section{Thought Action Fusion Questionnaire for Adolescents}

The Thought Action Fusion Questionnaire for Adolescents (TAFQ-A) (Muris, Meesters, Rassin, Merchelbach \& Campbell, 2001) is a 15 item self-report questionnaire. Information is gathered on two dimensions of thought action fusion (TAF) which are aggregated to yield a total score. The subscales are 'Morality' (the belief that unacceptable thoughts are morally equivalent to overt actions) and 'Likelihood' (the belief that thoughts about an unacceptable or disturbing situation will increase the probability that that situation will occur). Each item comprises a brief description of some situation (e.g., 'Suddenly, without any reason, you have the thought that you are hit by a car'), and asks how much the person agrees with a statement about that situation (e.g., 'Having this thought increases the risk that you really will be hit by a car') using a Likert scale (1 - 4). The TAFQ-A has been validated with a sample of 427 adolescents aged between 14 and 16 years (Muris et al., 2001). Factor analysis suggests two components: Moral TAF and Likelihood TAF. The two factors correlate moderately, $r(427)=0.33, p<0.001$. Overall internal consistency was reported to be good $(\alpha=0.84)$. Validity was found to be satisfactory. When state anxiety was controlled, regression analysis showed TAFQ - A score correlated most highly with OCD symptoms, and not with symptoms of depression or other anxiety disorders. Muris et al. (2001) reported a mean score of 22.2 and standard deviation of 6.4. This would suggest a cut-off of 35 (that is, 2 standard deviations above the mean).

\section{Child Responsibility Attitudes Scale}

The Child Responsibility Attitudes Scale (CRAS) (Salkovskis \& Williams, 2004b; Waite \& Williams 2009 - PLEASE SEE ADDITIONAL DOCUMENT) is an adaptation of the Responsibility Attitudes Scale (RAS) (Salkovskis, Wroe, Gledhill, Morrison, Forrester, et al., 2000). The CRAS is a 20 item, self report measure of general beliefs about responsibility. Each item is rated on a 
scale of 7 responses (totally agree, agree very much, agree slightly, neutral, disagree slightly, disagree very much, totally disagree). A low total score indicates a high level of responsibility attitudes. The RAS has good test-retest reliability $(r=.94)$ and high internal consistency (alpha $=.92$; Salkovskis et al., 2000). Initial reports on the psychometric properties of the CRAS (Griffen, 2000) indicate high internal consistency (Cronbach's alpha, $\alpha=0.85$ ) and concurrent validity. When piloted with a non-clinical sample of 210 adolescents (aged $13-14$ years) the mean score was 64.7, with standard deviation of 15 (Griffen, 2000).

\section{Researcher Administered Measures}

\section{Origins Questionnaire for Adolescents}

The Origins Questionnaire for Adolescents (OQA - PLEASE SEE ADDITIONAL DOCUMENT) is a semi-structured interview tool for use with adolescents who have received a diagnosis of OCD. There are 10 questions, comprising 54 items. It investigates experiences of responsibility from each of the five pathways proposed by Salkovskis et al. (1999). It was adapted from the Origins Questionnaire (OQ) (Salkovskis, personal communication, July, 2007) for the current study. The OQA differs from the $O Q$ in that items are made age appropriate for the adolescent population (e.g., "stressful experiences at work" is changed to "stressful issues at school"). The adapted measure was discussed with experts within the field of adult and adolescent OCD, who considered appropriate amendments to have been made. The OQA is completed by the researcher interviewing an adolescent. Item responses are given in one of five categories (18 items require a response stating the age at which a young person was expected or allowed to do some activity, e.g., 'Choose what time to go to bed'; 15 items require a response stating how true, from 0 to 100, a statement is about them, e.g., 'I had duties that prevented harm coming to other people'; 2 items require a qualitative response, e.g., 'Has anything ever happened to you that changed or confirmed your views about harm?'; 6 items require a yes / no response, e.g., 'Do you believe in magic'; 3 items require a response stating how responsible a young person 
felt for some event, e.g., 'How responsible did you feel for the harm in an incident you witnessed in which someone else was harmed').

The OQA comprises 5 subscales: 1) Broad sense of responsibility, 2) Rigid codes of conduct, 3) Shielded from responsibility, 4) Specific incidents with some negative outcome and, 5) Extremes of responsibility. These subscales relate to the 5 proposed pathways as shown in Figure 1.

\section{Parent Questionnaire Measures}

\section{Child Development Questionnaire - Revised}

The Child Development Questionnaire - Revised (CDQ-R) (S. Perrin, personal communication, 2008 - PLEASE SEE ADDITIONAL DOCUMENT) is an 18 question version of the Child Development Questionnaire (Zabin \& Melamed, 1980); each question requiring a response in each of five categories. The questionnaire assesses parents' reported disciplinary behaviours used with their child in situations where their child faced feared situations. Parents' disciplinary behaviours are categorized according to the following five learning principles: positive reinforcement of coping in children; punishment; force; reinforcement of dependency; and modeling and reassurance. Zabin and Melamed (1980) found the predictive validity of the questionnaire to be good (via correlations with a measure of the child's anxiety in a feared situation).

\section{Independent Living Questionnaire}

The Independent Living Questionnaire (ILQ) (PLEASE SEE ADDITIONAL DOCUMENT) is derived from the Origins Questionnaire, and was designed to be completed by parents of adolescents with a history of OCD. Items were altered from the $\mathrm{OQ}$ to gather information from parents about their child's experiences of responsibility during development. There are 11 questions, requiring comprising 46 items.

\section{Data Collection}


Data were gathered at participants' homes. Measures were administered in the same order with each participant (for adolescents: CRAS; Child OCI; TAFQ-A; OQA; for parents: ILQ; CDQ-R; EAS).

Ethical approval was obtained from Mid \& South Buckinghamshire NHS Research Ethics Committee (REC ref 08/H0607/90). Informed consent was obtained from all participants directly prior to data collection. All participants were given a box of chocolates.

\section{Reliability of the OQA Design and Procedure}

The reliability of the measure was investigated with data gathered from a separate sample. Participants were recruited from the University of Reading student panel. Participants in the reliability study completed the OQA with the researcher in a university laboratory during work hours on two occasions separated by one week. Participants received credit toward their course of study for each of the two interviews they completed. Ethical approval was obtained from University of Reading Ethics Committee. Information sheets were given to all participants and informed consent was obtained from all participants directly prior to data collection. 


\title{
RESULTS
}

\section{Sample Characteristics:}

\author{
Gender and Age:
}

In the main study, adolescent participants in each group were 5 males and 11 females. In the clinical group average adolescent age was 17.3 years $(S D=2.13)$, and in the non-clinical group 16.8 years $(S D=.96)$. Parent participants in the clinical group were 15 mothers and 4 fathers. Parent measures were received from parents of 14 adolescents in the non-clinical group of whom 13 were mothers and 2 were fathers.

\section{Statistical Methods:}

Tests for normality of the distribution of data were carried out for all variables using the Kolmogorov-Smirnov test. Responses provided by adolescent participants in both groups were normally distributed for all data except the TAFQ-A, Child OCI and the OQA subscale 3) 'Shielded from responsibility'. Transforming the data for these variables failed to produce a normal distribution. These variables were analysed using non-parametric tests. Responses provided by parents were normally distributed for all data except the CDQ-R subscales of 'Punishment' and 'Force'; and the ILQ subscale 'Specific incidents with a negative outcome'. Transforming the data for these variables failed to produce a normal distribution. These variables were analysed using non-parametric tests.

One tailed t-tests were used to compare mean differences between clinical and nonclinical groups, where a difference in a specific direction was expected. For all variables, it was predicted that the clinical group would score higher than the non-clinical group. Levene's test for equality of variance was used where a different distribution of responses was expected between 
clinical and non-clinical groups. Where variables were not normally distributed, KolmogorovSmirnov $\mathrm{Z}$ tests were used to compare the two groups.

Following Rothman (1990), due to the exploratory nature of this study, adjustments for multiple comparisons were not made as these would increase the potential to reject significant differences between groups at an exploratory stage, and therefore increase the chances of closing off potentially interesting avenues of exploration in subsequent work.

\section{Descriptive Measures:}

Mean scores and standard deviations for the self-report questionnaire measures (CRAS, Child OCI, TAFQ-A completed by adolescents and CDQ-Revised completed by parents) are provided in Table 1.

Using t-tests and Kolmogorov-Smirnov Z tests, no significant differences were found between the adolescent groups. Statistics for these were as follows: CRAS, $t(30)=-.96, p=.17$; on the Child OCI, $(z=1.10, p=.10)$; on the TAFQ-A, $(z=.88, p=.21)$. The scores of parents of adolescent participants on the CDQ-R and EAS scale were also compared to see if they differed significantly between groups. Groups differed on only one variable, the EAS subscale, 'Emotionality', $t(28)=2.3, p<.05)$ with the OCD parent group scoring higher than the non-OCD parent group. On all other variables, there were no significant differences between groups. Statistics for these were as follows: CDQ-R subscales 'Positive Reinforcement', $t(28)=1.1, p=$ .14 ; 'Punishment', $(z=-.49, p=.65)$; 'Force', $(z=.97, p=.09)$; 'Reinforcement of Dependency', $t(28)=-.84, p=.20 ;$ 'Modelling and Reassurance', $t(28)=-.95, p=.18$.

INSERT TABLE 1 ABOUT HERE 
On the CRAS, where a lower score indicates a greater sense of responsibility, neither group scored in the clinical range (64 was the mean score in a non-clinical sample reported by Griffen, 2000). On the Child OCI, neither group scored above the clinical cut-off of 60 , though five clinical participants scored above this cut-off; and on the TAFQ-A, neither group's score was two standard deviations above the mean score of 22.2 reported by Muris et al. (2001). Taken together, these descriptive statistics suggest that the groups did not differ in terms of current OCD symptomatology, inflated responsibility appraisals or TAF. This increases our confidence that any differences between groups in terms of experiences on the OQA subscales are not due to a halo effect from current OCD symptomatology, but due to experiences of responsibility during development.

\section{Research Questions}

Table 2 shows mean scores for adolescents and their parents on subscales 1), 2), 3) and 4) ('Broad sense of responsibility', 'Rigid codes of conduct', 'Shielded from responsibility' and 'Specific Incidents with a negative outcome', respectively) of the OQA and ILQ. (Results from subscale 5, ‘Extremes of responsibility’ are reported separately.)

\section{INSERT TABLE 2 ABOUT HERE}

Table 2 shows that responses from adolescents did not differ significantly on subscales 1), 2) or 3) of the OQA; 'Broad sense of responsibility', 'Rigid codes of conduct', and 'Shielded from responsibility'. Parents reported no significant differences on subscales 1), 2) and 3) of the ILQ. Research questions 1, 2 and 3 can be answered negatively.

On OQA subscale 4), 'Specific incidents with a negative outcome', 13 participants (7 clinical) reported a sense of responsibility for some event with a negative outcome that occurred 
prior to the onset of OCD. The OCD group reported a significantly higher sense of responsibility for these events. It was not possible to calculate any comparison for subscale 4) of the ILQ, as only 3 parents ( 2 clinical) reported that their children felt a sense of responsibility for a significant event with a negative outcome. Research question 4 can be answered affirmatively.

OQA subscale 5), 'Extremes of responsibility', comprises items considering the ages at which a person was expected or allowed to do a certain activity (e.g., 'go on a bus or train alone'). Analyses from responses on this subscale were conducted on an item by item basis. This is because, were a person to report a low age on one item, and a high age on another item, aggregating that individual's responses could mask any extremes of responsibility they reported. Table 3 shows analyses for equality of the variances of responses on the 15 items on the subscale as reported by adolescents and their parents.

By adolescent report, the clinical and non-clinical groups' responses were distributed in a significantly different way on the item 'Choose your own clothes' $F(1,30)=7.26, p<.01$. By parent report, the groups had significantly different variances on the items 'Stay home alone' $F(1,28)=4.8, p<.05$ and 'Go out alone' $F(1,28)=5.2, p<.05$. Figure 2 shows these distributions graphically.

There were trends toward significance by adolescent report on the item 'Make or buy own lunch for school' $F(1,29)=3.79, p=.06$, and by parent report on the item 'Go shopping with a friend' $F(1,28)=3.27, p=.08$. Research question 5 cannot be answered affirmatively.

\section{INSERT TABLE 3 ABOUT HERE}

Figure 2 shows that, by adolescent report on the item 'Choose own clothes', the difference in variation is in the direction that would be expected - polarization of responses by clinical participants when compared to non-clinical participants. By parent report, however, the trend is for polarization of the experiences of non-clinical adolescents. More parents of non- 
clinical adolescents reported that either their children were allowed to go out alone or stay at home alone at a younger age than did parents of clinical participants, or that they were first allowed to do these activities at an older age than did parents of clinical adolescents.

\section{INSERT FIGURE 2 ABOUT HERE}

\section{Reliability of the OQA}

Reliability of the OQA was assessed in terms of internal consistency and test-retest reliability.

\section{Internal consistency}

This was assessed for the three subscales where items would theoretically be expected to demonstrate internal consistency; 1) 'Broad sense of responsibility', 2) 'Rigid codes of conduct' and 3) 'Shielded from responsibility'. Cronbach's alpha coefficients for these subscales are shown in Table 4. (The other two subscales of the OQA, subscale 4) 'Specific incidents associated with some negative outcome' and subscale 5) 'Extremes of responsibility', would not be expected to show internal consistency, and measures of their internal consistency are therefore not reported.

\section{INSERT TABLE 4 ABOUT HERE}

Analyses suggested that the internal consistency of the subscales would benefit from the removal of an item from subscales 1) and 2). From subscale 1), removing the item 'I had too many duties' would improve internal consistency with changes from $\alpha=.705$ to $\alpha=.716$ in the clinical group, and from $\alpha=.290$ to $\alpha=.377$ in the non-clinical group. From subscale 2 ), removing the item 'My parents were very strict' would improve internal consistency with changes from $\alpha=.284$ to $\alpha=.576$ in the clinical group. 
Following Kline's (1999) guidance that alpha coefficients should be between 0.7 and 0.8 , the alpha coefficients for these subscales are not ideal. On subscale 1), the alpha is in the appropriate range for the clinical group, but not the non-clinical group. On subscale 2), alphas were not in the appropriate range for either group. Subscale 3), however, has alphas in the appropriate range for both groups. 


\section{Test retest reliability}

The test retest reliability of the measure was investigated with a sample of 14 students from the University of Reading student panel. Participants were 4 males and 10 females. Of these, 4 males and 8 females completed the measure at times one and two. The average age of these participants was 20.8 years $(S D=1.8)$.

Intraclass correlation coefficients were calculated for all items to establish the test retest reliability of the measure. Analyses were conducted on all 5 subscales. The intraclass correlations are shown in Table 5. All of these correlations suggest that the measure is fairly stable over a period of one to two weeks.

\section{INSERT TABLE 5 ABOUT HERE}

\section{DISCUSSION}

The results of the main study suggest that there are few significant differences between adolescents with a history of OCD and non-clinical adolescents in terms of their experiences of responsibility during development. Research questions 1,2 and 3, relating to pathways 1, 2 and 3, respectively, were all answered negatively; no differences were found between groups on subscales 1), 2) or 3). Research question 5, which related to pathways 1 and 3, cannot be answered unequivocally. By adolescent report, the OCD group reported experiences in keeping with pathways 1 and 3. By parent report, however, the non-clinical group had experiences in keeping with pathways 1 and 3 . The answer to research question 4 , regarding pathways 4 and 5, was affirmative; the OCD group reported a greater sense of responsibility on subscale 4).

The internal consistency of the OQA was found to vary between subscales and between groups, with alphas between .377 and .880 . The test-retest reliability was in the appropriate range, intraclass coefficients were high, in the range .838 to .954 . The OQA appears to be reliable over time, but internal consistency is only partly satisfactory. 


\section{Discussion of Research Questions}

The results show that the experiences of adolescents in the two groups do not differ in the two groups do not differ in terms of an over encouraged sense of responsibility (pathway 1) a particularly rigid code of conduct (pathway 2) or being shielded from responsibility (pathway 3). There was a difference between the two groups in terms of experienced responsibility for specific incidents (pathways 4 and 5). Five explanations are offered for these results, which are that a) there is a cognitive vulnerability factor that can interact with specific events; b) reporting was subject to an anxiety recall bias; c) the OQA does not differentiate between experiences on pathway 4, where a person is responsible for some negative outcome, and pathway 5 , where a person is not responsible for a negative outcome, but incorrectly perceives that they are responsible; d) the OQA is an insensitive measure of experiences of responsibility during development and; e) an inflated sense of responsibility is not of central importance in OCD.

In the main study, of the 32 adolescent participants, a subset of 13 reported experiencing at least one significant event with a negative outcome, where they believed they could have influenced that outcome. Within this subset, the ratings of perceived responsibility for that negative outcome were significantly higher in the OCD group. This suggests that a tendency to perceive a high sense of responsibility for negative outcomes, where one believes one could influence that outcome, might pre-date the time when a person first notices their OCD symptoms. This is consistent with the idea of an inflated sense of responsibility as a vulnerability factor for development of OCD. It appears, however, in light of the lack of systematic and significant difference between groups on pathways 1,2 and 3, that the vulnerability factor might be limited to an inflated sense of responsibility for specific significant events. This vulnerability might be seen to be dependent upon occurrence of specific events with a negative outcome for self or other. It would not be a necessary or sufficient feature in the explanation of the 
development of OCD, as only seven of sixteen participants in the OCD group in this study reported such an event. This finding is also open, however, to alternative practical and theoretical explanations.

From a practical perspective, it might be that, because data were collected retrospectively, participants' recall of how responsible they felt at the time of the incident was affected by memory bias associated with anxiety symptoms. That is, one would report a higher sense of responsibility when one has elevated anxiety symptoms. Research regarding memory bias associated with anxiety in adolescents, however, does not suggest that there is clear evidence for an anxiety-related memory bias (Muris \& Field, 2008; Watts \& Weems, 2006). This explanation is also unappealing in light of the lack of differences between groups on the Child OCI, CRAS and TAFQ-A, which suggest that the clinical group was neither currently symptomatic nor subject to cognitive biases associated with OCD.

Theoretically, it might be that the OCD group had more experiences of incidents on pathway 4, where they were actually responsible for some negative outcome, whilst the nonclinical group tended to report experiences of incidents on pathway 5, where they were not responsible because their involvement with the event was only coincidental. It could be that the OCD group reported a greater sense of responsibility not because of an inflated sense of responsibility, but because they were responsible for the significant incidents they reported, whilst the non-OCD group were not responsible for the incidents they reported. The design of the OQA subscale 4), however, does not allow for this information to be established. (To obtain this information reliably would require a report from a third party who could provide information regarding the participants' 'objective' responsibility. Parents might not be a suitable source of this information, as only 3 parents reported their offspring to have been involved in incidents with a negative outcome, compared to 13 adolescents. This is to say, if the parent was not aware of their child's involvement in the incident, they would not be able to report on their child's responsibility for the outcome of that incident.) 
An alternative explanation for the lack of significant differences between groups on subscales 1), 2) and 3), and inconsistent differences by parent and adolescent report on subscale 5), is that the measures used to detect differences (OQA and ILQ) were insensitive to different experiences on pathways 1, 2 and 3. Salkovskis et al. (1999) suggested that the development of an inflated sense of responsibility might take the form of an accumulation of multiple small experiences, each of which has nugatory effect in isolation. Although very few differences were reported by groups in terms of their experiences of responsibility on pathways 1, 2 and 3, a difference was reported in terms of pathways 4 and 5 . The fundamental difference between pathways 1, 2 and 3 on the one hand, and pathways 4 and 5 on the other, are that on the first hand, experiences all occur over a protracted period, while those on the other hand are one-off significant incidents. In terms of being able to detect the subtleties of the processes involved on pathways 1, 2 and 3, it might be that retrospective measures such as the OQA and ILQ have inadequate sensitivity. Events with a significant impact, however, are, by definition, not subtle, and would require less sensitivity to detect. Whilst this study did detect a difference between groups in terms of significant experiences, it detected only one difference by adolescent report and two differences by parent report in terms of small experiences. Even where significant differences were detected, however, only one of three was in the expected direction. Alternatively, rather than the one-off nature of the events accounting for the fdifferences, it could be that the development of the OQA and ILQ was not adequately rigorous to yield a sensitive retrospective measure. Coles and Schofield (2008) provide a model for the development of a sensitive retrospective measure, the Pathways to Inflated Responsibility Beliefs Scale (PIRBS). This was developed in two parts, with an initial exploratory factor analysis followed by a confirmatory factor analysis that yielded a reliable and valid measure.

Alternatively, the OQA and ILQ might be suitably sensitive, but an inflated sense of responsibility is not centrally important in the development of OCD. The lack of systematic difference between groups on pathways 1,2 and 3 in this study is in keeping with experimental 
evidence in children with OCD (Barrett \& Healy-Farrell, 2003). The authors showed that an inflated sense of responsibility is not associated with increased anxiety, distress, or avoidance behaviours. An inflated sense of responsibility has also been shown to be non-specific to OCD, it is found in children with other anxiety disorders (Barrett \& Healy, 2003). This is consistent with an explanation of a sense of inflated responsibility in OCD as part of a post hoc rational explanation for compulsive behaviours. Swedo, Rapoport, Leonard, Lenane and Cheslow (1989) reported that $40 \%$ of children with OCD had no obsessive thoughts, only compulsive behaviours which, if not performed, left them with a sense of discomfort. In an ethological view of OCD, compulsive behaviours are seen as displacement behaviours, which provide an illusion of control in one's environment (Bolton, 1996). Compulsive behaviours would have a functional benefit akin to that of magical thinking seen in infants - that is, to reduce anxiety about the uncontrollability of factors important to the infant. Obsessions would be secondary to the compulsive behaviours insofar as, when a person is first aware of their compulsions, they might feel a need to propose some explanation for why they engaged in those compulsive behaviours. If this is the case, the explanation for one's otherwise inexplicable behaviours would also bring relief, not from the distressing compulsions, but from a concern that one is engaging in meaningless behaviours. This study did not consider the importance of having some explanation for why one engages in compulsive behaviours, and whether it would be distressing to have no explanation. Future studies could consider this issue by examining whether those who report no explanation for why they engage in compulsive behaviours tend to report more distress than do those who do have some explanation for their compulsions.

The clinical sample comprised 16 adolescents, of whom only 5 reported current clinical symptomatology on the Child OCI. Two strengths warrant consideration. First, the disorder will have been present for less time than in studies with adults, minimizing the influence of OCD on participants' sense of responsibility and its measurement. Second, the majority of the sample was not in an active phase of OCD illness. It is therefore unlikely that there would be a halo 
effect from current symptoms to reports of inflated responsibility. This lends support to the nature of differences reported by adolescents being a vulnerability factor for development of OCD, as these differences are not related to a current sense of inflated responsibility. This consideration is also applicable to the reported temperamental difference between groups, in that OCD was not currently present in the majority of the sample, and is less likely to have influenced parent reports of temperament.

Information in this study was collected retrospectively, and therefore has inherent limitations. These include that adolescent participants' responses regarding their experiences of responsibility during development were reliant on their ability to recall information from a period of potentially 21 years ago. Additionally, where parents of participants had more than one child, their recall of the experiences of responsibility of the child taking part in the study might have become confused with their other children's experiences of responsibility during development. The reliability and validity of the information, therefore, warrants some caution in the interpretation of information gathered retrospectively (that is, using the OQA and ILQ).

The sample is potentially limited in two ways. First, the sample is small. It was not possible to conduct a power calculation regarding a necessary sample size to detect significant differences between groups in terms of their experiences of responsibility, as none of the Origins Questionnaires or Independent Living Questionnaires have psychometric properties available that are necessary for such a calculation. The sample size was therefore guided by consultation with a statistics advisor and comparison with previous studies of OCD related cognitive phenomena using novel measures in adolescent samples (e.g., Barrett \& Healy, 2003; Bolton, Dearsley, Madronal-Luque \& Baron-Cohen, 2002).

Second, the clinical sample was not assessed within the study for a diagnosis of OCD. Rather, all cases were identified from CAMHS records as cases where a primary diagnosis of OCD had been made previously. It might be the case, therefore, that the process of ascertainment used differed between participants, and that the sample could be more 
representative of a clinical sample in terms of those treated for a primary diagnosis of OCD, rather than a clinical sample in terms of having met the diagnostic criteria of one of the two most commonly used classification systems (DSM-IV, (APA, 1994) or ICD 10, (WHO, 1992)).

The current study suggests that experiences of specific incidents with a negative outcome over which one perceives a high sense of responsibility are a risk factor for subsequent development of OCD. In light of this, clinical work in cases of OCD might benefit from incorporation of both assessment of any such experiences, and intervention to support accurate perception of responsibility for such specific incidents.

With this finding in mind, there is also an implication in terms of prevention of the development of OCD. In keeping with research regarding effective promotion of socio-emotional health in schools (Ohl, Mitchell, Cassidy \& Fox 2008; Stallard, Simpson, Anderson, Hibbert \& Osborn, 2006), it might be possible to incorporate an element in programmes to aid accurate evaluation of personal responsibility for significant events with a negative outcome. This element could be similar to tools used in clinical practice to address an inflated sense of responsibility, such as using a pie chart to apportion responsibility to multiple influences.

Findings from the current study suggest that the experiences of responsibility of adolescents with a history of OCD are broadly similar to adolescents without a history of OCD, except for significant events with a negative outcome. Future studies of the development of an inflated sense of responsibility would benefit from a closer focus on the additive effects of seemingly insignificant experiences. In keeping with Salkovskis et al. (1999), this task will be complex, due to the possibility of interacting types of influence on the development of an inflated sense of responsibility.

To build on the finding of the current study, future research might use a prospective design to investigate the development of an at-risk group. The group could be characterized by a high rating of Emotionality on the EAS, to establish what factors, including experiences of responsibility, might interact in the development of OCD. 
Research that incorporates investigation of protective factors is also likely to be helpful in delineating the interactions between the risk factors associated with temperament and experiences of responsibility. OCD appears to be a multi-factorial disorder, with multiple factors accounting for its development, and it is therefore likely to prove illuminating to investigate the interaction of multiple factors in the process of development. 


\section{REFERENCES}

American Psychiatric Association. (1994). Diagnostic and statistical manual of mental disorders (4th ed.). Washington, DC: Author.

Barrett, P. and Healy, L. (2003). An examination of the cognitive processes involved in childhood obsessive-compulsive disorder. Behaviour Research and Therapy, 41, 285299.

Barrett, P. and Healy-Farrell, L. (2003). Perceived responsibility in juvenile obsessivecompulsive disorder: An experimental manipulation. Journal of Clinical Child and Adolescent Psychology, 32, 430-441.

Barrett, P.M., Shortt, A. and Healy, L. (2002). Do parent and child behaviours differentiate families whose children have obsessive-compulsive disorder from other clinic and nonclinic families. Journal of Child Psychology and Psychiatry, 43, 597 - 607.

Beck, A.T., (1976). Cognitive therapy and the Emotional Disorders. International Universities Press: New York.

Bolton, D. (1996). Annotation: Developmental Issues in Obsessive-Compulsive Disorder. Journal of Child Psychology and Psychiatry, 37, 131 - 137.

Bolton, D., Dearsley, P. Madronal-Luque and Baron-Cohen, S. (2002). Magical thinking in childhood and adolescence: Development and relation to obsessive compulsion. British Journal of Developmental Psychology, 20, 479-494. 
Buss, A.H. and Plomin, R. (1984). Temperament. Early developing personality traits. London: Lawrence Erlbaum Associates.

Carter, A.S. and Pollock, R.A. (2000). Obsessive-compulsive disorder in childhood. Current Opinions in Pediatrics, 12, $325-330$.

Chambless, D.L., Gillis, M.M., Tran, G.Q., and Steketee, G.S. (1996). Parental bonding reports of clients with obsessive-compulsive disorder and agoraphobia. Clinical Psychology and Psychotherapy, $3,77-85$.

Chowdhury, U., Frampton, I. and Heyman, I. (2004). Clinical characteristics of young people referred to an obsessive-compulsive clinic in the United Kingdom. Clinical Child Psychology and Psychiatry, 9, $395-401$.

Coles, M.E., Schofield, C.A. (2008). Assessing the Development of Inflated Responsibility Beliefs: The Pathways to Inflated Responsibility Beliefs Scale. Behavior Therapy, 39, $322-335$.

Douglass, H.M., Moffitt, T.E., Dar, R., McGee, R. \& Silva, P. (1995). Obsessive-compulsive disorder in a birth cohort of 18-year-olds: prevalence and predictors. Journal of the American Academy of Child and Adolescent Psychiatry, 34, 1424-1431.

Eley, T.C., Bolton, D., O' Connor, T.G., Perrin, S., Smith, P. and Plomin, R. (2003) A twin study of anxiety-related behaviours in pre-school children. Journal of Child Psychology and Psychiatry, 44, 945- 960. 
Flament, M.F., Whitaker, A., Rappoport, J.L., Davies, M., Berg, C.Z., Kalikow, K., Sceery, W., and Schaffer, D. (1988). Obsessive compulsive disorder in adolescence: an epidemiological study. Journal of the American Academy of Child and Adolescent Psychiatry, 27, $764-771$.

Foa, E. B., Kozak, M. J., Salkovskis, P., Coles, M. E., \& Amir, N. (1998). The validation of a new Obsessive-Compulsive Disorder scale: The Obsessive-Compulsive Inventory. Psychological Assessment, 10, 206-214.

Griffen, N. (2000). Unpublished master's thesis, University of Reading, UK.

Hanna, G.L. (1995). Demographic and Clinical Features of Obsessive-Compulsive Disorder in Children and Adolescents, American Journal of the Academy of Child and Adolescent Psychiatry, 34, 19-27.

Heyman, I., Fombonne, E., Simmons, H, Ford, T., Meltzer, H. and Goodman, R. (2003). Prevalence of obsessive-compulsive disorder in the British nationwide survey of child mental health. British Journal of Psychiatry, 179, 324 - 329.

Kline, P. (1999). The handbook of psychological testing ( $2^{\text {nd }}$ edition). London: Routledge.

Leckman, J.F., Zhang, H., Alsobrook, J.P., Pauls, D.L. (2001). Symptom dimensions in obsessive-compulsive disorder: toward quantitative phenotypes. American Journal of Medical Genetics, 105, 28-30. 
Lewinsohn, P.M., Hops, H., Roberts, R.E., Seeley, J.R. \& Andrews, J.A. (1993). Adolescent psychopathology: I. Prevalence and incidence of depression and other DSM-III-R disorders in high school students. Journal of Abnormal Psychology, 102, 133 - 144.

Libby, S., Reynolds, S., Derisley, J. and Clark, S. (2004). Cognitive appraisals in young people with obsessive-compulsive disorder. Journal of Child Psychology and Psychiatry, 45, 1076-1084.

Muris, P. (2006). The pathogenesis of childhood anxiety disorders: Considerations from a developmental psychopathology perspective. International Journal of Behavioral Disorders, 30, $5-11$.

Muris, P. and Field, A. (2008). Distorted cognition and pathological anxiety in children and adolescents. Cognition \& Emotion, 22, $395-421$.

Muris, P. Meesters, C., Rassin, E., Merchelbach, H. and Campbell, J. (2001). Thought-action fusion and anxiety disorders symptoms in normal adolescents. Behaviour Research and Therapy, 39, 843-852.

Ohl, M., Mitchell, K., Cassidy, T. and Fox, P. (2008). The Pyramid Club Primary School-Based Intervention: Evaluating the Impact on Children's Social-Emotional Health. Child and Adolescent Mental Health, 13, 115 - 121.

Pauls, D. L., Alsobrook, J. P., Goodman, W., Rasmussen, S. and Leckman, J. (1995). A family study of obsessive-compulsive disorder. American Journal of Psychiatry, 152, 76-84. 
Piacentini, J., Bergman, L., Keller, O. and McCracken, J. (2003). Functional impairment in children and adolescents with obsessive-compulsive disorder. Journal of Child and Adolescent Psychopharmacology, 13, 61-69.

Pollock, R.A., and Carter A.S. (1999). The familial and developmental context of obsessivecompulsive disorder. Child and Adolescent Psychiatric Clinics of North America, 8, 461 -479 .

Reeves, J. (2006). An experimental manipulation of responsibility in children: A test of the inflated responsibility model of obsessive-compulsive disorder. Thesis submitted in part fulfilment of the degree of Doctorate in Clinical Psychology, University of East Anglia.

Rasmussen, S. \& Eisen, J. (1998). The epidemiology and clinical features of obsessivecompulsive disorder. In M. Jenike, L. Baer \& W. Miniciello (Eds), ObsessiveCompulsive Disorders: Practical Management $3^{\text {rd }}$ Edition. St Louis, Missouri, USA: Mosby.

Rasmussen, S.A., and Eisen, J.L. (1990). Epidemiology of obsessive-compulsive disorder. Journal of Clinical Psychiatry, 53 (Supp.), $10-13$.

Rothman, K.J. (1990). No Adjustments Are Needed for Multiple Comparisons. Epidemiology, 1, $43-46$.

Salkovskis, P.M. (1985) Obsessive-compulsive problems: A cognitive-behavioural analysis. Behaviour Research and Therapy, 23, 571-583. 
Salkovskis, P.M. (1989).Cognitive behavioural factors and the persistence of intrusive thoughts in obsessional problems. In R.M. Rapee (Ed.) Current controversies in the anxiety disorders. New York: Guilford Press.

Salkovskis, P.M. and Harrison, J. (1984). Abnormal and normal obsessions - A replication. Behaviour Research and Therapy, 22, 549-552.

Salkovskis, P. and Williams, T. (2004a). Child Obsessive Compulsive Inventory (Child OCI). Unpublished manuscript.

Salkovskis, P. and Williams, T. (2004b). Child Responsibility Attitudes Scale. (CRAS). Unpublished manuscript.

Salkovskis, P., Shafran, R., Rachman, S. and Freeston, M.H. (1999). Multiple pathways to inflated responsibility beliefs in obsessional problems: possible origins and implications for therapy and research. Behaviour Research and Therapy, 37, 1055-1072.

Salkovskis, P.M., Wroe, A., Gledhill, A., Morrison, N., Forrester, E., Richards, H., Reynolds, M. and Thorpe, S. (2000). Responsibility attitudes and interpretations are characteristic of obsessive compulsive disorder. Behaviour Research and Therapy, 38, 347-372.

Shafran, R., Thordarson, D.S., \& Rachman, S. (1996). Thought-action fusion in obsessive compulsive disorder. Journal of Anxiety Disorders, 10, 379-391. 
Stallard, P., Simpson, N., Anderson, A., Hibbert, S. and Osborn, C. (2006). The FRIENDS Emotional Health Programme: Initial Findings from a School-Based Project. Child and Adolescent Mental Health, 12, $32-37$.

Swedo, S., Rapoport, J., Leonard, H., Lenane, M. and Cheslow, D. (1989). Obsessivecompulsive disorder in children and adolescents. Clinical phenomenology of 70 consecutive cases. Archives of General Psychiatry, 46, 335 - 341.

Uher R., Heyman I., Turner, C.M., Shafran, R. (2008). Self-, parent-report and interview measures of obsessive-compulsive disorder in children and adolescents. Journal of Anxiety Disorders, 22, $979-990$.

Van Ameringen, M., Mancini, C. and Oakman, J. (1998). The relationship of behavioural inhibition and shyness to anxiety disorder. Journal of Nervous and Mental Disease, $186,425-431$.

Waite, P. and Williams, T.I. (2009) Eds. Obsessive Compulsive Disorder: Cognitive Behaviour Therapy with Children and Young People. Routledge: London.

Watts, S. E. and Weems, C. (2006). Associations Among Selective Attentions, Memory Bias, Cognitive Errors and Symptoms of Anxiety in Youth. Journal of Abnormal Child Psychology, 34, $841-852$.

Williams, T, Salkovskis, P., Forrester, E. and Allsopp, M. (2002). Changes in symptoms of OCD and appraisal of responsibility during cognitive behavioural treatment: A pilot study. Behavioural and Cognitive Psychotherapy, 30, 69-78. 
Wells, A. (1997). Cognitive Therapy of anxiety disorders: a practice manual and conceptual guide. Chichester, UK: Wiley

World Health Organization (1992). The ICD-10 Classification of Mental and Behavioural Disorders. Clinical descriptions and diagnostic guidelines. Geneva: Author.

Zabin, M.A. and Melamed, B.G. (1980). Relationship Between Parental Discipline and Children's Ability to Cope with Stress. Journal of Abnormal Behaviour, 2, 17 - 38.

Zucker, B.G., Craske, M.G., Barrios, V. and Holguin, M. (2002). Thought action fusion: Can it be corrected? Behaviour Research and Therapy, 40, 653-664. 


\section{ADDITIONAL DOCUMENT}

Child Obsessive-Compulsive Inventory p2

Child Responsibility Attitudes Scale p4

Origins Questionnaire for Adolescents $\quad$ p6

The Child Development Questionnaire - Revised p9

$\begin{array}{ll}\text { Independent Living Questionnaire } & \text { p18 }\end{array}$ 
The following statements are about things that happen to many people in their everyday lives. For each statement, draw a circle around the number which says best how much it has troubled you in the last week.

\section{$0=$ has not troubled me at all. $\quad 1=$ troubled me a little. $\quad 2=$ definitely troubled me. $3=$ troubled me a Lot. \\ 4 = troubled me extremely}

\begin{tabular}{|c|c|c|c|c|c|}
\hline & $\begin{array}{l}\text { Not at } \\
\text { all }\end{array}$ & A little & Definitely & A lot & Extremely \\
\hline $\begin{array}{l}\text { Bad thoughts come into my mind even if I don't want them to, } \\
\text { and I can't get rid of them. }\end{array}$ & 0 & 1 & 2 & 3 & 4 \\
\hline $\begin{array}{l}\text { If I touch or if I'm near sweat, saliva, blood, or urine I might get } \\
\text { germs on my clothes or somehow be harmed. }\end{array}$ & 0 & 1 & 2 & 3 & 4 \\
\hline $\begin{array}{l}\text { I ask people to repeat things to me many times, even though I } \\
\text { knew what they meant the first time. }\end{array}$ & 0 & 1 & 2 & 3 & 4 \\
\hline I have to wash and clean all the time. & 0 & 1 & 2 & 3 & 4 \\
\hline $\begin{array}{l}\text { I have to think through things that happened in the past to make } \\
\text { sure that I didn't do something wrong. }\end{array}$ & 0 & 1 & 2 & 3 & 4 \\
\hline I have saved up so many things that they get in the way. & 0 & 1 & 2 & 3 & 4 \\
\hline I check things more often than I need to. & 0 & 1 & 2 & 3 & 4 \\
\hline $\begin{array}{l}\text { I try not to use public toilets because I am afraid of disease or } \\
\text { germs. }\end{array}$ & 0 & 1 & 2 & 3 & 4 \\
\hline I check doors, windows, drawers etc. over and over. & 0 & 1 & 2 & 3 & 4 \\
\hline $\begin{array}{l}\text { I check water taps and light switches over and over after turning } \\
\text { them off. }\end{array}$ & 0 & 1 & 2 & 3 & 4 \\
\hline I collect things I don't need. & 0 & 1 & 2 & 3 & 4 \\
\hline $\begin{array}{l}\text { I sometimes think I might have hurt someone without knowing } \\
\text { it. }\end{array}$ & 0 & 1 & 2 & 3 & 4 \\
\hline I have thoughts that I might want to hurt myself or others. & 0 & 1 & 2 & 3 & 4 \\
\hline I get upset if things are not arranged properly. & 0 & 1 & 2 & 3 & 4 \\
\hline $\begin{array}{l}\text { I have to follow a certain order in dressing, undressing and } \\
\text { washing myself. }\end{array}$ & 0 & 1 & 2 & 3 & 4 \\
\hline I feel I have to count while I am doing things. & 0 & 1 & 2 & 3 & 4 \\
\hline I am afraid of doing embarrassing or harmful things on impulse. & 0 & 1 & 2 & 3 & 4 \\
\hline I need to pray to stop bad thoughts or feelings. & 0 & 1 & 2 & 3 & 4 \\
\hline I keep on checking homework or other things I have written. & 0 & 1 & 2 & 3 & 4 \\
\hline $\begin{array}{l}\text { I get upset at the sight of knives, scissors and other sharp } \\
\text { objects in case I lose control with them. }\end{array}$ & 0 & 1 & 2 & 3 & 4 \\
\hline
\end{tabular}




\begin{tabular}{|c|c|c|c|c|c|}
\hline & $\begin{array}{l}\text { Not at } \\
\text { all }\end{array}$ & A little & Definitely & A lot & Extremely \\
\hline $\begin{array}{l}\text { I find it hard to touch an object when I know it has been touched } \\
\text { by strangers or certain people. }\end{array}$ & 0 & 1 & 2 & 3 & 4 \\
\hline I need things to be arranged in a certain order. & 0 & 1 & 2 & 3 & 4 \\
\hline $\begin{array}{l}\text { I get behind in my schoolwork because I do the same things } \\
\text { over and over again. }\end{array}$ & 0 & 1 & 2 & 3 & 4 \\
\hline I feel I have to repeat certain numbers. & 0 & 1 & 2 & 3 & 4 \\
\hline After doing something carefully, I still feel I have not finished it. & 0 & 1 & 2 & 3 & 4 \\
\hline I find it hard to touch rubbish or dirty things. & 0 & 1 & 2 & 3 & 4 \\
\hline I find it hard to control my own thoughts. & 0 & 1 & 2 & 3 & 4 \\
\hline I have to do things over and over again until it feels right. & 0 & 1 & 2 & 3 & 4 \\
\hline $\begin{array}{l}\text { I am upset by bad thoughts that come into my mind even } \\
\text { though I don't want them to. }\end{array}$ & 0 & 1 & 2 & 3 & 4 \\
\hline $\begin{array}{l}\text { Before going to sleep I have to do certain things in a certain } \\
\text { way. }\end{array}$ & 0 & 1 & 2 & 3 & 4 \\
\hline $\begin{array}{l}\text { I go back to places to make sure that I have not harmed } \\
\text { anyone. }\end{array}$ & 0 & 1 & 2 & 3 & 4 \\
\hline I often get nasty thoughts and it's hard to get rid of them. & 0 & 1 & 2 & 3 & 4 \\
\hline $\begin{array}{l}\text { I try not to throw things away because I am afraid I might need } \\
\text { them later. }\end{array}$ & 0 & 1 & 2 & 3 & 4 \\
\hline I get upset if others change the way I have arranged my things. & 0 & 1 & 2 & 3 & 4 \\
\hline $\begin{array}{l}\text { I feel that I must repeat certain words or phrases in my mind to } \\
\text { wipe out bad thoughts, bad feelings or bad things I do. }\end{array}$ & 0 & 1 & 2 & 3 & 4 \\
\hline $\begin{array}{l}\text { After I have done things, I'm never quite sure whether I really } \\
\text { did them. }\end{array}$ & 0 & 1 & 2 & 3 & 4 \\
\hline $\begin{array}{l}\text { I sometimes have to wash or clean myself just because I feel } \\
\text { have germs. }\end{array}$ & 0 & 1 & 2 & 3 & 4 \\
\hline I feel that there are good and bad numbers. & 0 & 1 & 2 & 3 & 4 \\
\hline I check anything which could go on fire over and over. & 0 & 1 & 2 & 3 & 4 \\
\hline $\begin{array}{l}\text { Even when I do something very carefully I feel that it is not quite } \\
\text { right. }\end{array}$ & 0 & 1 & 2 & 3 & 4 \\
\hline I wash my hands more often or longer than I need to. & 0 & 1 & 2 & 3 & 4 \\
\hline
\end{tabular}


This questionnaire lists beliefs which people sometimes have. Read each statement carefully and decide how much you agree or disagree with it.

For each of the beliefs, put a circle round the words which BEST DESCRIBE HOW YOU THINK. Choose only one answer for each attitude. Because people are different, there are no right or wrong answers.

To decide whether a given attitude is like your way of looking at things, simply keep in mind what you are like MOST OF THE TIME.

1. I often feel responsible for things that go wrong.

\begin{tabular}{|c|c|c|c|c|c|}
\hline $\begin{array}{l}\text { TOTALLY } \\
\text { AGREE }\end{array}$ & $\begin{array}{l}\text { AGREE VERY } \\
\text { MUCH }\end{array}$ & $\begin{array}{l}\text { AGREE } \\
\text { SLIGHTLY }\end{array}$ & NEUTRAL & $\begin{array}{l}\text { DISAGREE } \\
\text { SLIGHTLY }\end{array}$ & $\begin{array}{l}\text { DISAGREE } \\
\text { VERY MUCH }\end{array}$ \\
\hline
\end{tabular}

2. If I think bad things, this is as bad as doing bad things.

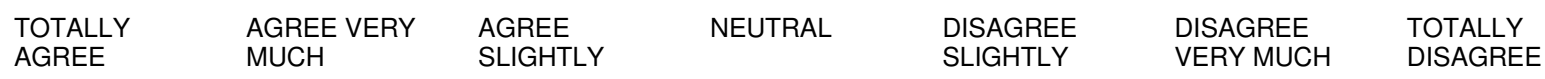

3. I worry a lot about what might happen because of things that I do or don't do.

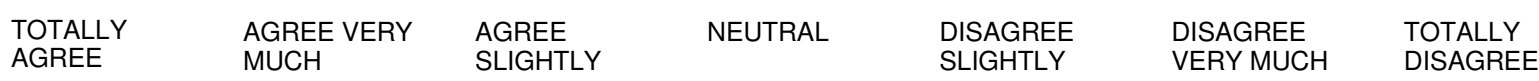

4. Not stopping bad things happening is as bad as making them happen.

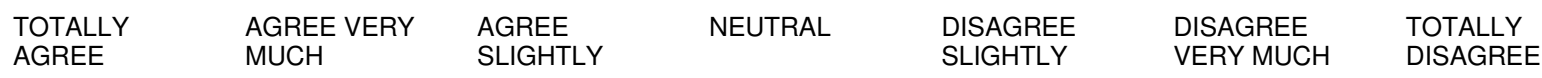

5. I should always try to stop harm happening, when I have thought it might.

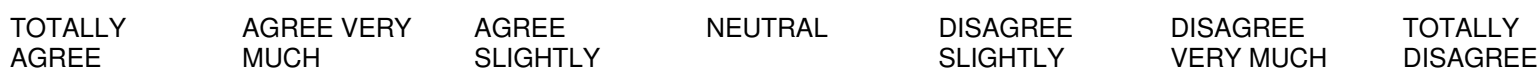

6. I must always think through what might happen as a result of even the smallest things I do.

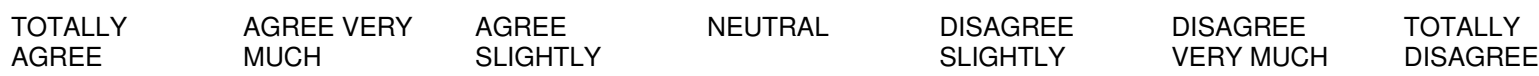

7. I often take responsibility for things which other people don't think are my fault.

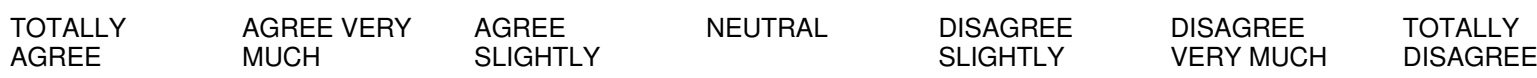

8. Everything I do can cause serious problems.

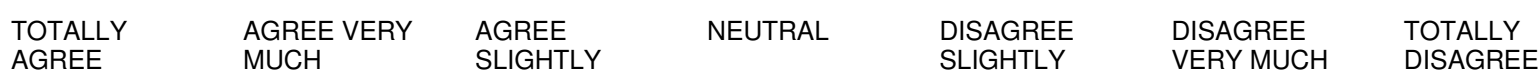

9. I often nearly cause harm

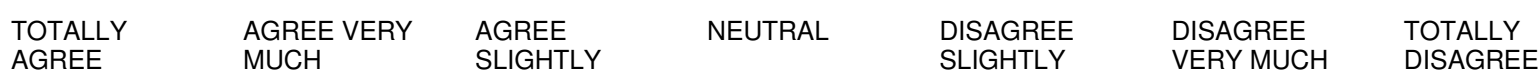


10. I must protect others from harm.

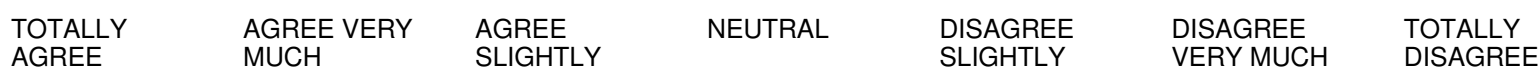

11. I should never cause even smallest amount of harm to others

\begin{tabular}{|c|c|c|c|}
\hline TOTALLY & & AGREE & NEUTRAL \\
\hline
\end{tabular}

12. I will be condemned for my actions.

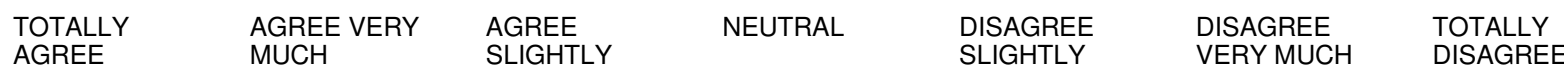

13. I must try to stop bad things from happening, if there is any chance that what I do might make a difference.

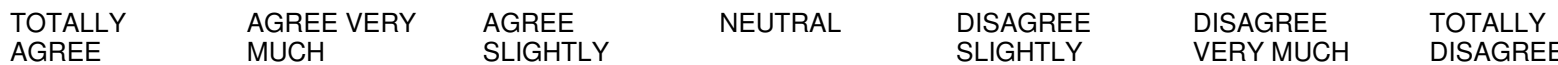

14. Doing nothing when bad things might happen is the same as making it happen.

$\begin{array}{lllll}\text { TOTALLY AGRE VERY AGREE } & \text { NEUTRAL DISAGREE } & \text { DISAGREE } & \text { TOTALLY }\end{array}$

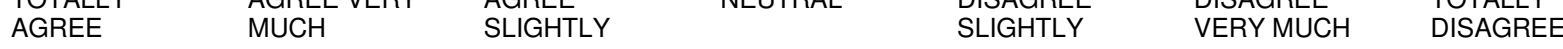

15. You should never be careless, when what you do might affect someone else.

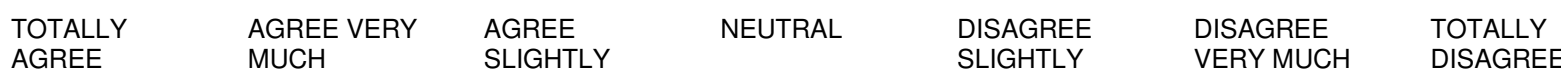

16. If I do nothing that can cause as much harm as doing something bad.

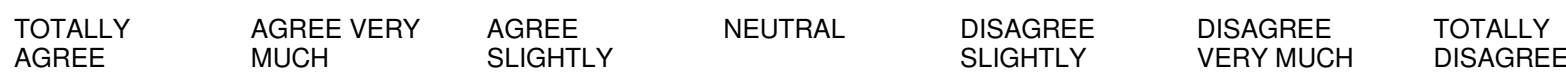

17. I can't forgive myself, once I think it is possible that I have caused harm.

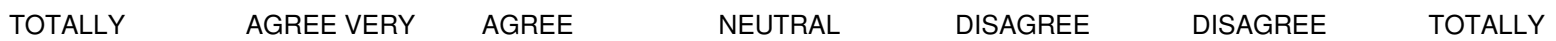



18. Lots of things I have done, have been meant to prevent harm to others.

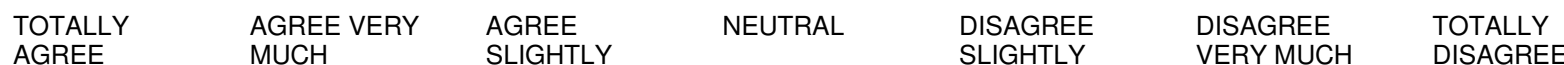

19. If I am careful enough then I can prevent any harmful accidents.

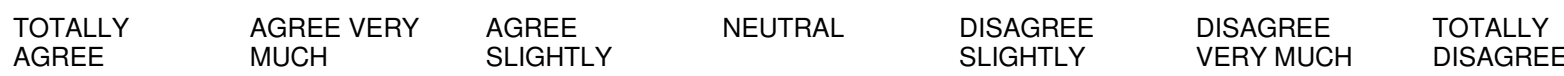

20. I often think that bad things will happen if I am not careful enough.

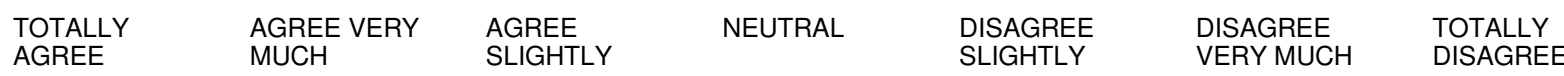




\section{Origins Questionnaire for Adolescents}

1. Please think back to the time when you were a child. At which age were you allowed to (or expected to):

$\begin{array}{llll}----- & \text { Choose your own clothes } & --- & \text { Choose what time to go to bed } \\ ----- & \text { Ride a bicycle } & ---- & \text { Go on a bus or train on your own } \\ ---- & \text { Stay at home on your own } & --- & \text { Make or buy your own lunch for school } \\ ---- & \text { Go out on your own } & ---- & \text { Be in sole charge of a pet } \\ ---- & \text { Stay at a relative's place overnight } & --- & \text { Babysit for a sibling or other child } \\ ---- & \text { Stay at a friend's place overnight } & ---- & \text { Go shopping with a friend } \\ ----- & \text { Go shopping on your own } & ---- & \text { Receive pocket money/allowance } \\ ---- & \text { Drive a car } & & \end{array}$

2. Please consider the following statements, and use a percentage to indicate how true they are for you:

0 -
Not true

---- As a child, I felt that there would always be someone (e.g. your parents) to give you support if things grew difficult

---- As a child, my parents would always blame me if I made a mistake

---- As a child, I always blamed myself if I made a mistake

---- $\quad$ My parents were very strict

---- $\quad$ My parents regarded things like orderliness, punctuality, neatness ... as important

---- I had many duties or obligations

3. If you had duties or obligations, what kind of duties? Please tick all that are appropriate.

Please write in at what age you had these responsibilities.

----- Looking after siblings -------------- at age--------------

---- Looking after an ill family member ------------- at age-------------

---- $\quad$ Duties in the household (please specify) -------------- at age--------------

4. Please use the following scale to rate these items:

0 - -100
Not true

---- I feel that the duties I had were too much for me

---- I had duties that prevented harm coming to people

---- I was brought up in a religious way (by my parents, in school)

---- $\quad$ The way I was brought up was characterized by high moral standards

Compared to other parents, my parents worried a lot 
7. a)Have you ever in your life witnessed an incident which harmed someone else? Did you have any influence or could you have influenced the outcome?

How responsible did you feel for the harm? $(0-100)$

7. b)Have you ever in your life been involved in an incident in which you were harmed? Did you have any influence or could you have influenced the outcome?

How responsible did you feel for the harm? $(0-100)$

8. a) Did it ever seem to you that good thoughts can come true? (Did you ever have a good thought that came true?)

8. b) Did it ever seem to you that bad thoughts can come true? (Did you ever have a bad thought that came true?) 
9. Do you believe in magic?

10. How well did your parents get along with each other?

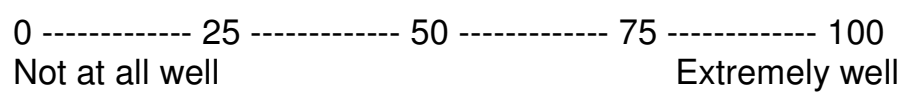

11. Did they often criticize and blame each other?

0 -

Never Always

12. Was there a time in your life when you felt you were getting bullied or badly teased?

How responsible did you feel for that? $(0-100)$

Thank you. 
The following items represent various situations which children often face while growing up. For each situation there are 5 responses, plus 'other'. Circle a number to indicate how often you used each of the responses (including 'other' if used). Therefore, please give a response for each possibility (a) to (e). If you find it necessary to use the 'other' category, write your responses clearly on the line next to the word 'other'. Please try to limit your use of this category.

\begin{tabular}{|c|c|c|c|c|c|}
\hline $\begin{array}{l}\text { 1. If I took my child to get a haircut and he/she } \\
\text { absolutely refused to sit on the chair because } \\
\text { he/she was frightened, I would most likely.... }\end{array}$ & 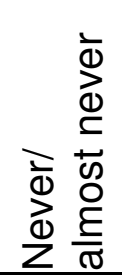 & $\frac{\overline{0}}{\frac{0}{\omega}}$ & 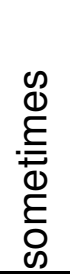 & $\underset{\frac{c}{\Phi}}{\stackrel{\frac{\pi}{L}}{0}}$ & 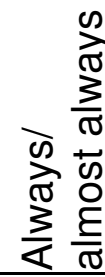 \\
\hline $\begin{array}{l}\text { Explain that children get their haircut all the } \\
\text { time and nothing bad happens to them }\end{array}$ & 1 & 2 & 3 & 4 & 5 \\
\hline $\begin{array}{l}\text { Tell my child that if he/she didn't sit down } \\
\text { he/she would get a mild spanking }\end{array}$ & 1 & 2 & 3 & 4 & 5 \\
\hline $\begin{array}{l}\text { Tell my child that if he/she sat in the chair } \\
\text { and behaved he/she would get a lollipop. }\end{array}$ & 1 & 2 & 3 & 4 & 5 \\
\hline Take my child home immediately & 1 & 2 & 3 & 4 & 5 \\
\hline $\begin{array}{l}\text { Put my child in the chair and hold him/her } \\
\text { there }\end{array}$ & 1 & 2 & 3 & 4 & 5 \\
\hline Other.. & 1 & 2 & 3 & 4 & 5 \\
\hline
\end{tabular}

\begin{tabular}{|c|c|c|c|c|c|}
\hline $\begin{array}{l}\text { 2. If my child was afraid to go near a small } \\
\text { harmless puppy, I would most likely... }\end{array}$ & 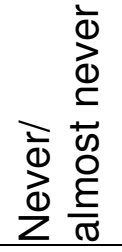 & 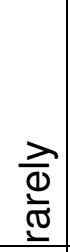 & 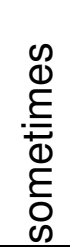 & $\frac{c}{\Phi}$ & 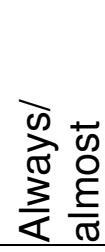 \\
\hline $\begin{array}{l}\text { Place my child's hand on the puppy against } \\
\text { his/her will }\end{array}$ & 1 & 2 & 3 & 4 & 5 \\
\hline Permit my child to stay away from the puppy & 1 & 2 & 3 & 4 & 5 \\
\hline $\begin{array}{l}\text { Tell my child that if he/she did not touch the } \\
\text { dog I would be ashamed of him/her }\end{array}$ & 1 & 2 & 3 & 4 & 5 \\
\hline $\begin{array}{l}\text { Pet the puppy to show the child it was } \\
\text { harmless }\end{array}$ & 1 & 2 & 3 & 4 & 5 \\
\hline $\begin{array}{l}\text { Tell my child that if he touched the dog it } \\
\text { would make me very happy }\end{array}$ & 1 & 2 & 3 & 4 & 5 \\
\hline Other.. & 1 & 2 & 3 & 4 & 5 \\
\hline
\end{tabular}




\begin{tabular}{|c|c|c|c|c|c|}
\hline $\begin{array}{l}\text { 3. If I took my child to the doctor's office to get an } \\
\text { injection and he/she ran out of the room when } \\
\text { he/she saw the needle, I would most likely... }\end{array}$ & 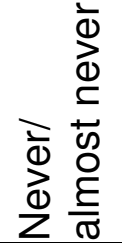 & $\frac{\overline{0}}{\stackrel{0}{\frac{0}{0}}}$ & 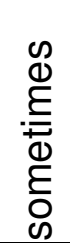 & $\underset{\Phi}{\Phi}$ & 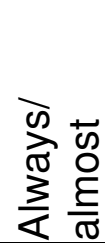 \\
\hline $\begin{array}{l}\text { Tell my child if she/he didn't come back she/he } \\
\text { would not be permitted to watch TV }\end{array}$ & 1 & 2 & 3 & 4 & 5 \\
\hline $\begin{array}{l}\text { Pull my child back into the room and hold } \\
\text { him/her while the doctor administered the injection }\end{array}$ & 1 & 2 & 3 & 4 & 5 \\
\hline $\begin{array}{l}\text { Tell the doctor we'd come back some other } \\
\text { time. }\end{array}$ & 1 & 2 & 3 & 4 & 5 \\
\hline $\begin{array}{l}\text { Tell my child that many of her/his friends get } \\
\text { shots and are not afraid }\end{array}$ & 1 & 2 & 3 & 4 & 5 \\
\hline $\begin{array}{l}\text { Tell my child if he/she came back and } \\
\text { cooperated with the doctor, l'd buy him an ice cream } \\
\text { cone. }\end{array}$ & 1 & 2 & 3 & 4 & 5 \\
\hline Other $\ldots \ldots \ldots \ldots \ldots \ldots \ldots \ldots \ldots \ldots \ldots \ldots \ldots \ldots \ldots$ & 1 & 2 & 3 & 4 & 5 \\
\hline
\end{tabular}

\begin{tabular}{|c|c|c|c|c|c|}
\hline $\begin{array}{l}\text { 4. If my child woke up in the middle of the night } \\
\text { complaining she/he had a bad dream and said } \\
\text { she/he would not go back to bed unless her/his } \\
\text { bedroom light was left on, I would most likely... }\end{array}$ & 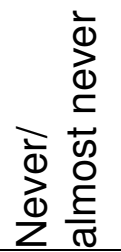 & $\begin{array}{l}\frac{\lambda}{0} \\
\frac{0}{\omega}\end{array}$ & 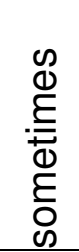 & $\underset{\Phi}{\Phi}$ & 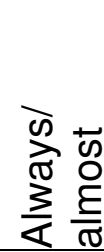 \\
\hline $\begin{array}{l}\text { Tell my child that if he/she did not return to } \\
\text { bed and leave the light off, he/she would not be able } \\
\text { to play with her/his friends }\end{array}$ & 1 & 2 & 3 & 4 & 5 \\
\hline $\begin{array}{l}\text { Allow my child to leave on a small hall or } \\
\text { bathroom light and gradually have her/him get used } \\
\text { to sleeping with no light at all. }\end{array}$ & 1 & 2 & 3 & 4 & 5 \\
\hline $\begin{array}{l}\text { Tell my child that if he/she went back to bed } \\
\text { with the light off, l'd give him/her a special treat. }\end{array}$ & 1 & 2 & 3 & 4 & 5 \\
\hline $\begin{array}{l}\text { Put my child into bed and fix it so she/he } \\
\text { could not turn on the light; e.g. .taking out the bulb }\end{array}$ & 1 & 2 & 3 & 4 & 5 \\
\hline Allow the light to be left on & 1 & 2 & 3 & 4 & 5 \\
\hline 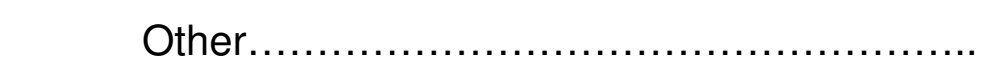 & 1 & 2 & 3 & 4 & 5 \\
\hline
\end{tabular}




\begin{tabular}{|c|c|c|c|c|c|}
\hline $\begin{array}{l}\text { 5. If while learning to ride a bicycle, my child fell } \\
\text { off, uninjured, and would not get back on, I } \\
\text { would most likely... }\end{array}$ & 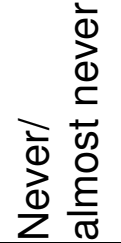 & $\begin{array}{l}\frac{\lambda}{0} \\
\frac{0}{0}\end{array}$ & 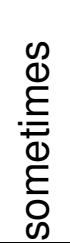 & 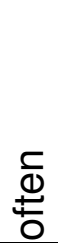 & 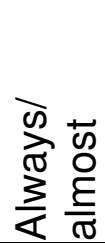 \\
\hline Allow him/her to practice some other time. & 1 & 2 & 3 & 4 & 5 \\
\hline $\begin{array}{l}\text { Tell my child that if she/he didn't learn to ride } \\
\text { a bike all the children in the street would laugh at } \\
\text { him/her }\end{array}$ & 1 & 2 & 3 & 4 & 5 \\
\hline $\begin{array}{l}\text { Get on the bicycle myself and show him/her } \\
\text { how easy if becomes with just a little more practice }\end{array}$ & 1 & 2 & 3 & 4 & 5 \\
\hline $\begin{array}{l}\text { Tell my child how proud l'd be if she/he tried } \\
\text { again }\end{array}$ & 1 & 2 & 3 & 4 & 5 \\
\hline $\begin{array}{l}\text { Lift my child onto the bicycle seat, against } \\
\text { his/her wishes }\end{array}$ & 1 & 2 & 3 & 4 & 5 \\
\hline Other... & 1 & 2 & 3 & 4 & 5 \\
\hline
\end{tabular}

\begin{tabular}{|c|c|c|c|c|c|}
\hline $\begin{array}{l}\text { 6. If it was my child's first exposure to the pool, } \\
\text { and he/she was frightened to go near the water, I } \\
\text { would most likely... }\end{array}$ & 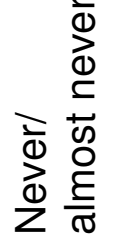 & $\frac{\overrightarrow{0}}{\frac{\bar{d}}{\sqrt{0}}}$ & 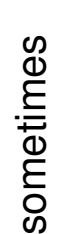 & $\underset{\Phi}{\Phi}$ & 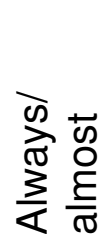 \\
\hline $\begin{array}{l}\text { Take my child and place him/her in the water } \\
\text { against his/her will }\end{array}$ & 1 & 2 & 3 & 4 & 5 \\
\hline $\begin{array}{l}\text { Tell my child that if he/she went into the water, } \\
\text { l'd think he/she was a great swimmer }\end{array}$ & 1 & 2 & 3 & 4 & 5 \\
\hline $\begin{array}{l}\text { Gradually get used to the water by first } \\
\text { wetting her/his hands and feet. }\end{array}$ & 1 & 2 & 3 & 4 & 5 \\
\hline Permit him/her to stay out of the water & 1 & 2 & 3 & 4 & 5 \\
\hline $\begin{array}{l}\text { Tell my child if he/she didn't go into the water, } \\
\text { l'd think he/she was a chicken. }\end{array}$ & 1 & 2 & 3 & 4 & 5 \\
\hline Other..... & 1 & 2 & 3 & 4 & 5 \\
\hline
\end{tabular}




\begin{tabular}{|c|c|c|c|c|c|}
\hline $\begin{array}{l}\text { 7. If my child was afraid of thunder and lightning } \\
\text { and wanted to come into bed with me at night, I } \\
\text { would most likely... }\end{array}$ & 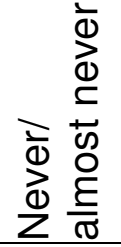 & 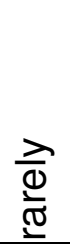 & 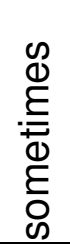 & $\frac{\frac{\sigma}{\Phi}}{\frac{t}{0}}$ &  \\
\hline $\begin{array}{l}\text { Tell my child that thunder and lightning were } \\
\text { only noises and lights in the far distance and could } \\
\text { not harm him/her while in his/her own bed. }\end{array}$ & 1 & 2 & 3 & 4 & 5 \\
\hline $\begin{array}{l}\text { Take my child back to his/her room, put } \\
\text { him/her to bed, and shut the door. }\end{array}$ & 1 & 2 & 3 & 4 & 5 \\
\hline $\begin{array}{l}\text { Tell my child that if he/she did not sleep in } \\
\text { his/her own bed, he/she would be behaving like a } \\
\text { baby. }\end{array}$ & 1 & 2 & 3 & 4 & 5 \\
\hline $\begin{array}{l}\text { Tell my child that if she/he went back to } \\
\text { his/her own bed, she/he would be able to stay up } \\
\text { later the next night. }\end{array}$ & 1 & 2 & 3 & 4 & 5 \\
\hline Let him/her sleep with me & 1 & 2 & 3 & 4 & 5 \\
\hline 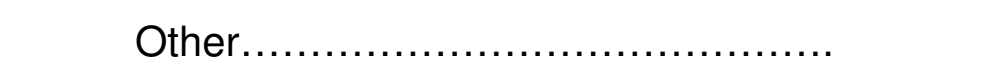 & 1 & 2 & 3 & 4 & 5 \\
\hline
\end{tabular}

\begin{tabular}{|c|c|c|c|c|c|}
\hline $\begin{array}{l}\text { 8. If while on a school trip, my child became } \\
\text { terribly homesick and asked to be taken home, I } \\
\text { would most likely.... }\end{array}$ & 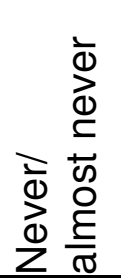 & 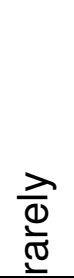 & 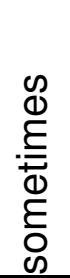 & 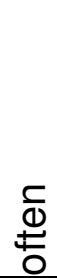 & 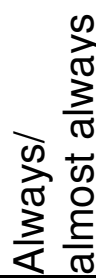 \\
\hline $\begin{array}{l}\text { Tell my child that if she/he didn't stop her/his } \\
\text { behavior, all the children and teachers would be very } \\
\text { upset with him/her. }\end{array}$ & 1 & 2 & 3 & 4 & 5 \\
\hline $\begin{array}{l}\text { Tell him/her that other children go on school } \\
\text { trips and are never homesick. }\end{array}$ & 1 & 2 & 3 & 4 & 5 \\
\hline Taker her/him home. & 1 & 2 & 3 & 4 & 5 \\
\hline $\begin{array}{l}\text { Tell my child that if he/she stayed, he/she } \\
\text { would prove to everyone how very grown up and } \\
\text { mature he/she was. }\end{array}$ & 1 & 2 & 3 & 4 & 5 \\
\hline $\begin{array}{l}\text { Ignore my child's pleas to come home and } \\
\text { leave him/her on the school trip until it was time to } \\
\text { return. }\end{array}$ & 1 & 2 & 3 & 4 & 5 \\
\hline Other... & 1 & 2 & 3 & 4 & 5 \\
\hline
\end{tabular}


9. If my child became very frightened on the day he/she had to do a presentation in school and said he/she would refuse to do it, I would most likely....

\begin{tabular}{|c|c|c|c|c|c|}
\hline $\begin{array}{c}\text { Ask the teacher to excuse my child from doing } \\
\text { the presentation. }\end{array}$ & 1 & 2 & 3 & 4 & 5 \\
\hline $\begin{array}{c}\text { Make sure my child gave his/her presentation, } \\
\text { even if I had to take her/him to the front of the } \\
\text { classroom. }\end{array}$ & 1 & 2 & 3 & 4 & 5 \\
\hline $\begin{array}{c}\text { Tell my child that if he/she gave the talk I } \\
\text { would buy him/her a surprise. }\end{array}$ & 1 & 2 & 3 & 4 & 5 \\
\hline $\begin{array}{c}\text { Tell my child that, once in front of the class, } \\
\text { his/her fear would disappear quickly. }\end{array}$ & 1 & 2 & 3 & 4 & 5 \\
\hline $\begin{array}{c}\text { Tell my child that if she/he didn't give his/her } \\
\text { presentation the teacher would give her/him a bad } \\
\text { mark. }\end{array}$ & 1 & 2 & 3 & 4 & 5 \\
\hline Other..................................................... & 1 & 2 & 3 & 4 & 5 \\
\hline
\end{tabular}

\section{If my child expressed great fear when he/she learned that he/she must go to the hospital for a tonsillectomy, an decided that he/she would not go, I would most likely...}

\begin{tabular}{|c|c|c|c|c|c|}
\hline $\begin{array}{c}\text { Tell my child that if she/he didn't have the } \\
\text { operation, she/he would become very sick }\end{array}$ & 1 & 2 & 3 & 4 & 5 \\
\hline $\begin{array}{c}\text { See if the operation could be postponed to a } \\
\text { later date }\end{array}$ & 1 & 2 & 3 & 4 & 5 \\
\hline $\begin{array}{c}\text { Tell my child that the hospital has excellent } \\
\text { doctors and nurses who would take good care of } \\
\text { him/her. }\end{array}$ & 1 & 2 & 3 & 4 & 5 \\
\hline $\begin{array}{c}\text { Tell my child that if she/he went to the hospital } \\
\text { and had the operation, the family would make a party } \\
\text { for him/her when he/she returned. }\end{array}$ & 1 & 2 & 3 & 4 & 5 \\
\hline $\begin{array}{c}\text { Tell my child that whether he/she liked it or } \\
\text { not, he/she was going to hospital. }\end{array}$ & 1 & 2 & 3 & 4 & 5 \\
\hline $\begin{array}{c}\text { Other.................................................. } \\
\text { Othe }\end{array}$ & 1 & 2 & 3 & 4 & 5 \\
\hline
\end{tabular}




\begin{tabular}{|c|c|c|c|c|c|}
\hline $\begin{array}{l}\text { 11. If I took my child to get a filling, and because } \\
\text { of her/his great fear she/he was unable to } \\
\text { cooperate with the dentist, I would most likely... }\end{array}$ & 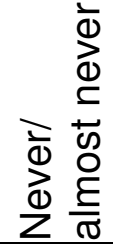 & $\begin{array}{l}\frac{\lambda}{00} \\
\frac{0}{00}\end{array}$ & 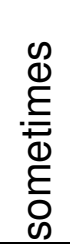 & $\underset{\Phi}{\Phi}$ & 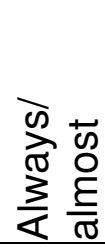 \\
\hline $\begin{array}{l}\text { Tell my child that if he/she cooperated with } \\
\text { the dentist, he/she could invite a friend to sleep that } \\
\text { evening at our house }\end{array}$ & 1 & 2 & 3 & 4 & 5 \\
\hline $\begin{array}{l}\text { Hold my child still in the chair, against his/her } \\
\text { will while the dentist drilled his/her teeth. }\end{array}$ & 1 & 2 & 3 & 4 & 5 \\
\hline $\begin{array}{l}\text { Tell my child that I've had my teeth drilled } \\
\text { many times and that it hurts just a little for a short } \\
\text { time. }\end{array}$ & 1 & 2 & 3 & 4 & 5 \\
\hline Take my child home & 1 & 2 & 3 & 4 & 5 \\
\hline $\begin{array}{l}\text { Tell my child that if she/he did not let the } \\
\text { dentist take care of her/him, her/his teeth would rot } \\
\text { and perhaps fall out. }\end{array}$ & 1 & 2 & 3 & 4 & 5 \\
\hline Other............. & 1 & 2 & 3 & 4 & 5 \\
\hline
\end{tabular}

\begin{tabular}{|c|c|c|c|c|c|}
\hline $\begin{array}{l}\text { 12. If my child refused to open a cupboard } \\
\text { because he/she thought there was a ghost } \\
\text { inside, I would most likely... }\end{array}$ & 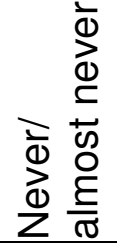 & $\frac{\overrightarrow{\bar{d}}}{\frac{0}{\sqrt[0]{0}}}$ &  & $\underset{\Phi}{\Phi}$ & 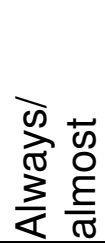 \\
\hline $\begin{array}{l}\text { Tell my child how shocked and disappointed I } \\
\text { was that she/he would not open the door }\end{array}$ & 1 & 2 & 3 & 4 & 5 \\
\hline $\begin{array}{l}\text { Tell my child that if she/he opened the door I } \\
\text { would think he/she was a hero }\end{array}$ & 1 & 2 & 3 & 4 & 5 \\
\hline $\begin{array}{l}\text { Take my child, unwillingly, by the hand and } \\
\text { have her/him open the door. }\end{array}$ & 1 & 2 & 3 & 4 & 5 \\
\hline $\begin{array}{l}\text { Open the door myself to show him/her no } \\
\text { ghost existed }\end{array}$ & 1 & 2 & 3 & 4 & 5 \\
\hline Let her/him leave the door closed. & 1 & 2 & 3 & 4 & 5 \\
\hline Other.................. & 1 & 2 & 3 & 4 & 5 \\
\hline
\end{tabular}


13. If my child would not leave the house because he/she was afraid that the child next door would tease him/her and call him/her names, I would most likely...

\begin{tabular}{|c|c|c|c|c|c|}
\hline $\begin{array}{c}\text { Tell my child that his/her friend is not afraid of } \\
\text { the child next door. }\end{array}$ & 1 & 2 & 3 & 4 & 5 \\
\hline $\begin{array}{c}\text { Tell my child that if he/she didn't leave the } \\
\text { house he/she would be put to bed early }\end{array}$ & 1 & 2 & 3 & 4 & 5 \\
\hline $\begin{array}{c}\text { Let my child remain in the house } \\
\text { Take my child, unwillingly, outside and have }\end{array}$ & 1 & 2 & 3 & 4 & 5 \\
\hline $\begin{array}{c}\text { him/her confront the child next door. } \\
\text { Tell my child that if he/she went outside }\end{array}$ & 1 & 2 & 3 & 4 & 5 \\
\hline $\begin{array}{c}\text { he/she could watch his/her favourite TV show. } \\
\text { Other................................................ }\end{array}$ & 1 & 2 & 3 & 4 & 5 \\
\hline
\end{tabular}

\begin{tabular}{|c|c|c|c|c|c|}
\hline $\begin{array}{l}\text { 14. If I told my child that my partner and I were } \\
\text { leaving him/her with a friend while we went away } \\
\text { for a few days, and she/he appeared very } \\
\text { frightened and said she/he would not sleep in } \\
\text { anyone's home but his/her own, I would most } \\
\text { likely... }\end{array}$ & 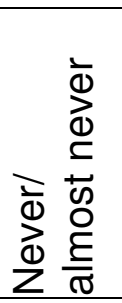 & $\begin{array}{l}\frac{\lambda}{\overline{0}} \\
\frac{\vec{\omega}}{\underline{\omega}}\end{array}$ & 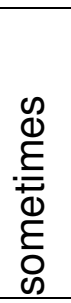 & 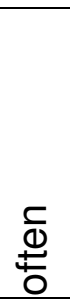 & 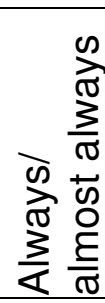 \\
\hline $\begin{array}{l}\text { Tell my child that he/she had no choice in the } \\
\text { matter and had to go. }\end{array}$ & 1 & 2 & 3 & 4 & 5 \\
\hline $\begin{array}{l}\text { Tell my child that we'd only be gone for a few } \\
\text { days and we would be home before he/she knew it. }\end{array}$ & 1 & 2 & 3 & 4 & 5 \\
\hline $\begin{array}{l}\text { Tell my child that if he/she didn't go, we'd } \\
\text { leave him/her at home on the next trip that the family } \\
\text { took together }\end{array}$ & 1 & 2 & 3 & 4 & 5 \\
\hline $\begin{array}{l}\text { See if it was possible if a friend of relative } \\
\text { could come to sleep with her/him in our own home. }\end{array}$ & 1 & 2 & 3 & 4 & 5 \\
\hline $\begin{array}{l}\text { Tell my child that if he/she went willingly, we } \\
\text { would all go for a Saturday outing to the park or zoo, } \\
\text { when we returned. }\end{array}$ & 1 & 2 & 3 & 4 & 5 \\
\hline Other....... & 1 & 2 & 3 & 4 & 5 \\
\hline
\end{tabular}




\begin{tabular}{|c|c|c|c|c|c|}
\hline $\begin{array}{l}\text { 15. If I was out in the park with my child when } \\
\text { they drop a favourite toy onto the path; the child } \\
\text { picks it up and says that they are worried it fell } \\
\text { near dog poo, but it doesn't appear to be dirty, I } \\
\text { would most likely... }\end{array}$ & 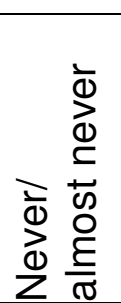 & $\frac{\overrightarrow{\bar{\omega}}}{\frac{\vec{\omega}}{\underline{\omega}}}$ & 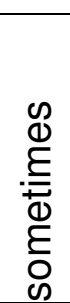 &  & 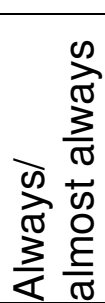 \\
\hline Tell the child to carry on and play with the toy & 1 & 2 & 3 & 4 & 5 \\
\hline Make the child carry the toy home & 1 & 2 & 3 & 4 & 5 \\
\hline $\begin{array}{l}\text { Say that you would buy an ice cream to make } \\
\text { them feel better. }\end{array}$ & 1 & 2 & 3 & 4 & 5 \\
\hline $\begin{array}{l}\text { Put the toy in a plastic bag and say you'll } \\
\text { wash it when you get home. }\end{array}$ & 1 & 2 & 3 & 4 & 5 \\
\hline $\begin{array}{l}\text { Tell them you can't see anything on it and it } \\
\text { looks ok. }\end{array}$ & 1 & 2 & 3 & 4 & 5 \\
\hline Other.. & 1 & 2 & 3 & 4 & 5 \\
\hline
\end{tabular}

\begin{tabular}{|c|c|c|c|c|c|}
\hline $\begin{array}{l}\text { 16. If my child comes home from school and is } \\
\text { very worried as it was their turn to feed the } \\
\text { school pet today and they don't remember if they } \\
\text { did it or not, I would most likely... }\end{array}$ & 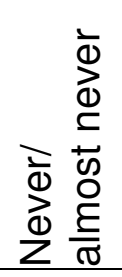 & $\frac{\overline{0}}{\frac{0}{0}}$ & 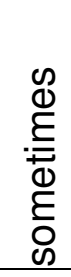 & $\frac{\bar{c}}{\Phi}$ & 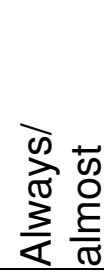 \\
\hline $\begin{array}{l}\text { Check with a teacher as soon as possible by } \\
\text { ringing the school. }\end{array}$ & 1 & 2 & 3 & 4 & 5 \\
\hline $\begin{array}{l}\text { Tell them not to worry as it won't matter to } \\
\text { miss one day. }\end{array}$ & 1 & 2 & 3 & 4 & 5 \\
\hline $\begin{array}{l}\text { Tell them you're disappointed because they're } \\
\text { making a fuss. }\end{array}$ & 1 & 2 & 3 & 4 & 5 \\
\hline $\begin{array}{l}\text { Tell them you don't want to hear any more } \\
\text { about it and that you won't listen if they keep talking } \\
\text { about it. }\end{array}$ & 1 & 2 & 3 & 4 & 5 \\
\hline $\begin{array}{l}\text { Offer them a treat if they go and do something } \\
\text { else to try and forget about it. }\end{array}$ & 1 & 2 & 3 & 4 & 5 \\
\hline Other.. & 1 & 2 & 3 & 4 & 5 \\
\hline
\end{tabular}




\begin{tabular}{|c|c|c|c|c|c|}
\hline $\begin{array}{l}\text { 17. If my child asks me not to take them to } \\
\text { school in the car as they have had a thought that } \\
\text { I might die in an accident I would most likely... }\end{array}$ & 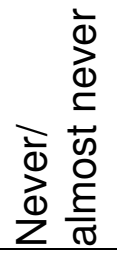 & $\begin{array}{l}\frac{\lambda}{00} \\
\frac{0}{\sqrt{0}}\end{array}$ &  & $\frac{c}{\frac{c}{ \pm}}$ & 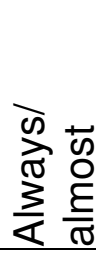 \\
\hline $\begin{array}{l}\text { Tell my child not to worry as I go in the car all } \\
\text { the time and it is very unlikely. }\end{array}$ & 1 & 2 & 3 & 4 & 5 \\
\hline $\begin{array}{l}\text { Tell my child that if they didn't get in the car I } \\
\text { won't let them visit their friend. }\end{array}$ & 1 & 2 & 3 & 4 & 5 \\
\hline Promise my child that I won't go out in the car & 1 & 2 & 3 & 4 & 5 \\
\hline $\begin{array}{l}\text { Tell my child not to be so silly and make them } \\
\text { get in the car. }\end{array}$ & 1 & 2 & 3 & 4 & 5 \\
\hline $\begin{array}{l}\text { Say that you'll give them a treat if they go in } \\
\text { the car. }\end{array}$ & 1 & 2 & 3 & 4 & 5 \\
\hline Other....................... & 1 & 2 & 3 & 4 & 5 \\
\hline
\end{tabular}

\begin{tabular}{|c|c|c|c|c|c|}
\hline $\begin{array}{l}\text { 18. If I notice my child touching and counting } \\
\text { things a certain amount of times until it 'feels } \\
\text { right', and this is interfering with their daily } \\
\text { routine I would most likely.... }\end{array}$ & 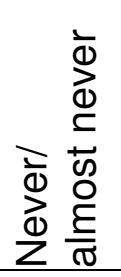 & $\frac{\overrightarrow{0}}{\frac{0}{\omega}}$ & 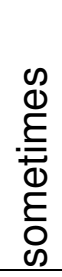 & 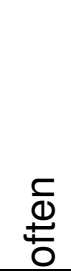 & 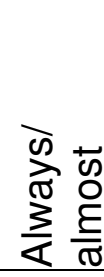 \\
\hline $\begin{array}{l}\text { Say that there is no need to do this, and if } \\
\text { they try not to, things will be alright anyway }\end{array}$ & 1 & 2 & 3 & 4 & 5 \\
\hline $\begin{array}{l}\text { Prevent them from doing this by telling them } \\
\text { off or holding their hands when you see it }\end{array}$ & 1 & 2 & 3 & 4 & 5 \\
\hline Tell my child l'll get them a video if they stop & 1 & 2 & 3 & 4 & 5 \\
\hline $\begin{array}{l}\text { Say that it's ok as long as it makes them feel } \\
\text { better }\end{array}$ & 1 & 2 & 3 & 4 & 5 \\
\hline $\begin{array}{l}\text { Tell them this is a really silly habit and they } \\
\text { won't be allowed to watch tv if they carry on. }\end{array}$ & 1 & 2 & 3 & 4 & 5 \\
\hline Other................. & 1 & 2 & 3 & 4 & 5 \\
\hline
\end{tabular}




\section{Independent Living Questionnaire}

1. At what age did you allow your child to (or expect them to):

$\begin{array}{llll}---- & \text { Choose their own clothes } & --- & \text { Choose what time to go to bed } \\ ---- & \text { Ride a bicycle } & --- & \text { Go on a bus or train on their own } \\ ---- & \text { Stay at home on their own } & --- & \text { Make or buy their own lunch for school } \\ ---- & \text { Go out on their own } & --- & \text { Babysit for a sibling or other child } \\ ---- & \text { Stay at a relative's place overnight } & --- & \text { Be in sole charge of a pet } \\ ---- & \text { Stay at a friend's place overnight } & --- & \text { Go shopping with a friend } \\ ---- & \text { Go shopping on their own } & ---- & \text { Receive pocket money / allowance } \\ ---- & \text { Drive a car }\end{array}$

2. Please consider the following statements, and use a percentage to indicate how true they are for your child:

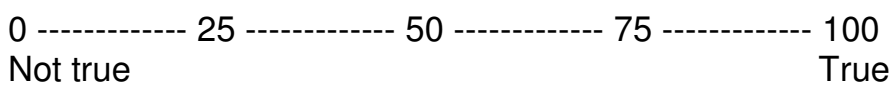

---- $\quad$ As a child, they felt that there would always be someone (for example, their parents) to give them support if things grew difficult

---- $\quad$ As a child, you would always blame them if they made a mistake

---- $\quad$ As a child, they always blamed themselves if they made a mistake

----- You were very strict

---- $\quad$ You regarded things like orderliness, punctuality, neatness... as important

---- $\quad$ They had many duties or obligations

3. If your child had duties or obligations, what kind of duties? Please tick all that are appropriate.

Please write in at what age they were given these responsibilities.

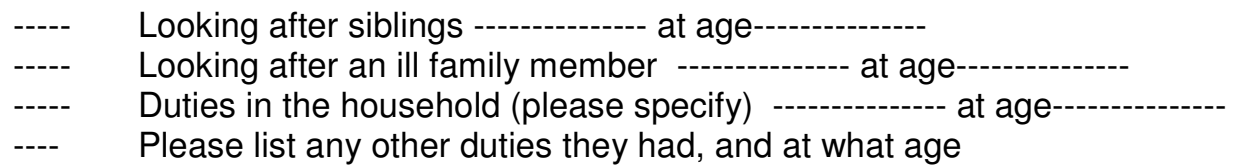

4. Please use the following scale to rate these items:

0 - $--\cdot-100$
Not true

---- $\quad$ They feel that the duties they had were too much for them

---- $\quad$ They had duties that prevented harm coming to people

---- $\quad$ They were brought up in a religious way (by you, in school)

---- $\quad$ The way they were brought up was characterized by high moral standards

---- Compared to other parents, you worried a lot

---- $\quad$ The way you or other adults treated them could be described as being wrapped in cotton wool

---- The way you or other adults treated them could be described as being spoon fed

---- $\quad$ They were overprotected

---- $\quad$ You encouraged them to try out new things 
You were always very careful - 'better safe than sorry'

5. How did you bring them up to prepare them for the responsibilities awaiting them in adult life?

(prompts: finances, going to the doctor, washing clothes?)

6. a)Have they ever in their life witnessed an incident which harmed someone else?

b)Did they have any influence or could they have influenced the outcome?

c)Did they feel responsible for the outcome?

(If so, please rate $0-100$ )

7. a)Have they ever in their life been involved in an incident which they were harmed? Did they have any influence or could they have influenced the outcome?

b)Did they have any influence or could they have influenced the outcome?

c)Did they feel responsible for the outcome?

(If so, please rate $0-100$ )

8. a) Did it ever seem to them that good thoughts can come true? (Did they ever have a good thought that came true?)

b) Did it ever seem to them that bad thoughts can come true? (Did they ever have a bad thought that came true?)

9. Do they believe in magic? 
Table 1

Descriptive Data and Statistics (Mean Scores, Group Differences) for Self-Report

Measures Completed by Adolescents and Parents

Table 2

Mean Scores, Standard Deviations, and Tests for Differences Between Clinical and Non-Clinical

Group Responses on the OQA and the ILQ

Table 3

Levene's Test for Equality of Variances on Items on 'Extremes of Responsibility' Subscale by

Adolescent and Parent Report

Table 4

Cronbach's Alpha Coefficients for OQA

Table 5

Mean Scores on Subscales of OQA at Test and Retest with Intraclass

Correlation Coefficients

Figure 1.

The relationship between subscales of the OQA and the proposed pathways to responsibility.

Figure 2.

Distributions of item responses on subscale 5, 'Extremes of responsibility', reported by adolescents and parents 


\section{Table 1}

\begin{tabular}{|c|c|c|c|c|c|c|c|c|c|}
\hline \multirow[t]{2}{*}{$\begin{array}{l}\text { Measure } \\
\text { (Subscale) }\end{array}$} & \multicolumn{2}{|c|}{$\begin{array}{l}\text { OCD } \\
\text { group }\end{array}$} & \multicolumn{2}{|c|}{$\begin{array}{l}\text { Non-OCD } \\
\text { group }\end{array}$} & \multicolumn{3}{|c|}{$T$ test } & \multicolumn{2}{|c|}{$\begin{array}{l}\text { Kolmogorov- } \\
\text { Smirnov Z }\end{array}$} \\
\hline & $M$ & & $M$ & (SD) & $d f$ & $t$ & $p$ & $z$ & $p$ \\
\hline CRAS & 76.5 & $(29.0)$ & 85.0 & $(20.1)$ & 30 & -.96 & .17 & & \\
\hline Child OCI & 37.5 & (27.8) & 24.3 & (26.4) & _- & _ & - & 1.1 &.$\overline{10}$ \\
\hline $\begin{array}{l}\text { TAFQ-A } \\
\text { CDQ-R }\end{array}$ & 24.7 & (9.9) & 21.4 & $(9.0)$ & - & - & - & .88 & .21 \\
\hline $\begin{array}{l}\text { (Positive } \\
\text { Reinforcement) }\end{array}$ & 42.8 & (10.9) & 38.7 & (7.7) & 28 & 1.1 & .14 & - & - \\
\hline (Punishment) & 23.4 & (7.7) & 22.8 & (3.1) & - & - & & -.49 & .65 \\
\hline (Force) & 24.5 & (7.8) & 25.2 & (4.9) & & - & - & .97 & .09 \\
\hline $\begin{array}{l}\text { (Reinforcement of } \\
\text { Dependency) }\end{array}$ & 47.3 & (7.9) & 49.8 & (8.2) & 28 & -.84 & .20 & - & - \\
\hline $\begin{array}{l}\text { (Modelling and } \\
\text { Reassurance) }\end{array}$ & 61.6 & (10.7) & 64.8 & (6.6) & 28 & -.95 & .18 & - & - \\
\hline
\end{tabular}

*indicates that mean scores differ significantly at $\mathrm{p}<.05$

RAS: Child Responsibility Attitudes Survey; Child OCI: Child Obsessive-Compulsive Inventory; TAFQ-A: Thought-Action Fusion Questionnaire for Adolescents; CDQ-R: Child Development Questionnaire Revised. 
Table 2

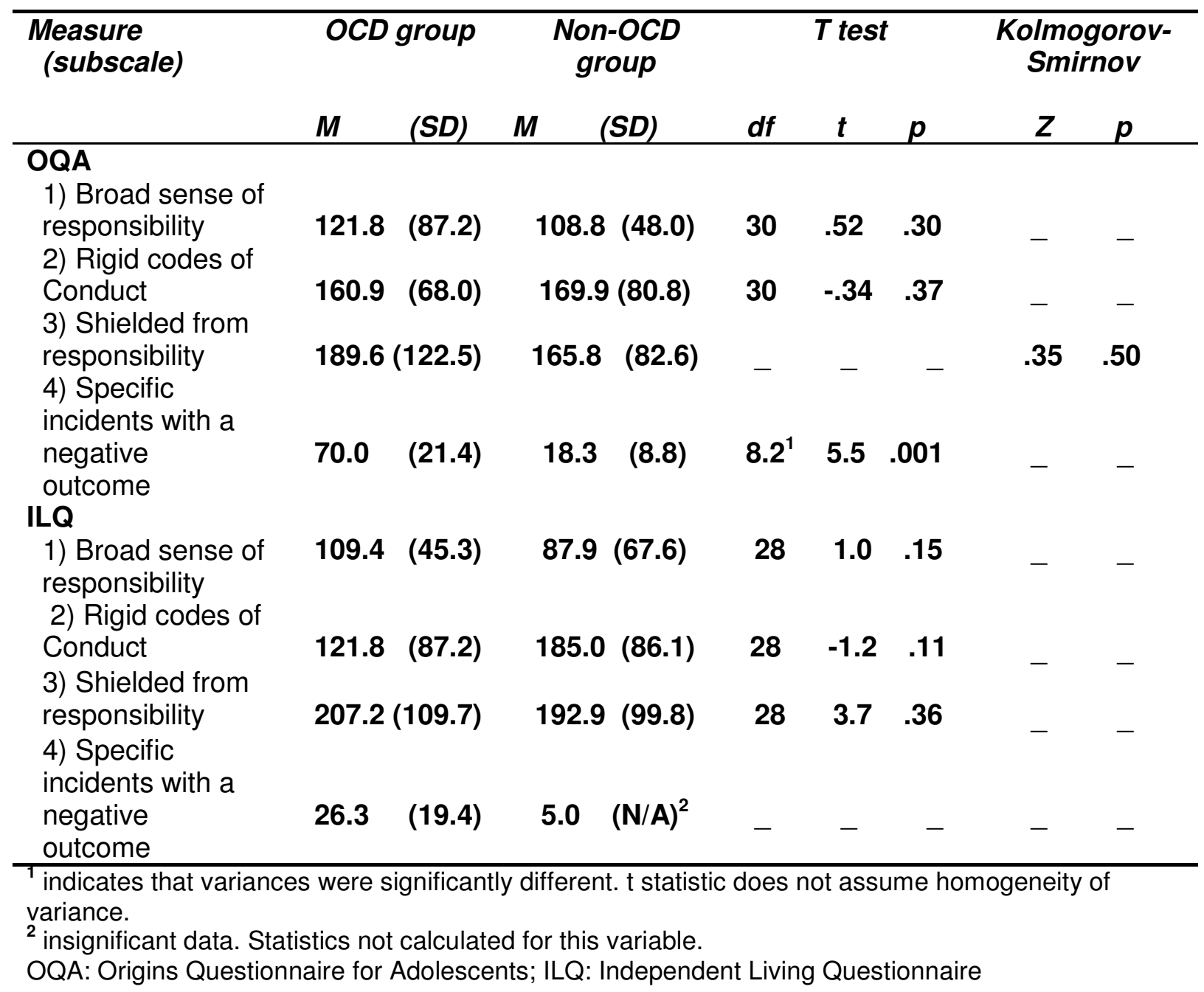


Table 3

\begin{tabular}{|c|c|c|c|c|c|c|c|c|}
\hline \multirow[b]{2}{*}{ OQA/ILQ item } & \multicolumn{4}{|c|}{ Adolescent report } & \multicolumn{4}{|c|}{ Parent report } \\
\hline & $d f 1$ & $d f 2$ & $\boldsymbol{F}$ & $p$ & $d f 1$ & $d f 2$ & $\boldsymbol{F}$ & $p$ \\
\hline Choose own clothes & 1 & 30 & 7.26 & $.01^{*}$ & 1 & 28 & .219 & .64 \\
\hline Ride a bike & 1 & 30 & .117 & .74 & 1 & 28 & .057 & .81 \\
\hline Stay home alone & 1 & 30 & .680 & .42 & 1 & 28 & 4.81 & $.04^{*}$ \\
\hline Go out alone & 1 & 29 & 2.89 & .10 & 1 & 28 & 5.20 & $.03^{*}$ \\
\hline $\begin{array}{l}\text { Stay at a relative's } \\
\text { overnight }\end{array}$ & 1 & 27 & .259 & .62 & 1 & 28 & .063 & .80 \\
\hline Stay at a friend's overnight & 1 & 29 & .425 & .52 & 1 & 28 & 1.89 & .18 \\
\hline Go shopping alone & 1 & 28 & 1.08 & .31 & 1 & 28 & .170 & .68 \\
\hline Go shopping with a friend & 1 & 29 & .450 & .51 & 1 & 28 & 3.27 & $.08^{t}$ \\
\hline $\begin{array}{l}\text { Receive pocket money / } \\
\text { allowance }\end{array}$ & 1 & 28 & .859 & .36 & 1 & 28 & .762 & .39 \\
\hline Drive a car ${ }^{\dagger}$ & - & - & - & - & 1 & 28 & 1.15 & .29 \\
\hline Choose bed time & 1 & 29 & .110 & .74 & 1 & 28 & .030 & .86 \\
\hline Go on a bus or train alone & 1 & 30 & 2.42 & .13 & 1 & 28 & .219 & .64 \\
\hline $\begin{array}{l}\text { Make or buy own school } \\
\text { lunch }\end{array}$ & 1 & 29 & 3.79 & $.06^{t}$ & 1 & 28 & .009 & .93 \\
\hline Be in sole charge of a pet & 1 & 19 & 1.39 & .25 & 1 & 28 & .038 & .85 \\
\hline Babysit & 1 & 27 & .833 & .37 & 1 & 18 & 2.16 & .16 \\
\hline
\end{tabular}

${ }^{*}$ Indicates significantly different variances; ${ }^{\mathbf{t}}$ indicates trend toward significant difference; ${ }^{\dagger}$ adolescents reported identical responses on this item. OQA: Origins Questionnaire for Adolescents; ILQ: Independent Living Questionnaire 
Table 4

\begin{tabular}{|c|c|c|c|}
\hline $\begin{array}{l}\text { Measure } \\
\text { (subscale) }\end{array}$ & Number of items & Clinical & Non-clinical \\
\hline \multicolumn{4}{|l|}{ OQA } \\
\hline $\begin{array}{l}\text { 1) Broad sense of } \\
\text { responsibility) }\end{array}$ & 4 & .716 & .377 \\
\hline $\begin{array}{l}\text { 2) Rigid codes of } \\
\text { conduct) }\end{array}$ & 3 & .576 & .685 \\
\hline $\begin{array}{l}\text { 3) Shielded from } \\
\text { responsibility) }\end{array}$ & 5 & .859 & .748 \\
\hline
\end{tabular}


Table 5

\begin{tabular}{|c|c|c|c|c|c|}
\hline \multirow{2}{*}{$\begin{array}{l}\text { Measure } \\
\text { (subscale) }\end{array}$} & \multicolumn{2}{|c|}{ Time 1} & \multicolumn{2}{|c|}{ Time 2} & \multirow[t]{2}{*}{$I C C$} \\
\hline & $M$ & $(S D)$ & $M$ & $(S D)$ & \\
\hline \multicolumn{6}{|l|}{ OQA } \\
\hline $\begin{array}{l}\text { 1) Broad sense of } \\
\text { responsibility) }\end{array}$ & 178.1 & (91.5) & 166.4 & (97.5) & .936 \\
\hline $\begin{array}{l}\text { 2) Rigid codes of } \\
\text { conduct) }\end{array}$ & 194.5 & $(80.9)$ & 208.5 & (89.4) & .954 \\
\hline $\begin{array}{l}\text { 3) Shielded from } \\
\text { responsibility) }\end{array}$ & 297.3 & (81.9) & 325.0 & $(64.3)$ & .838 \\
\hline $\begin{array}{l}\text { 4) Specific incidents } \\
\text { with a negative } \\
\text { outcome }\end{array}$ & 1.8 & $(1.0)$ & 2.0 & $(1.3)$ & .876 \\
\hline $\begin{array}{l}\text { 5) Extremes of } \\
\text { responsibility }\end{array}$ & 14.5 & $(2.4)$ & 14.1 & $(2.6)$ & .890 \\
\hline
\end{tabular}


4) Incident associated with negative outcome.

5) Extremes of responsibility

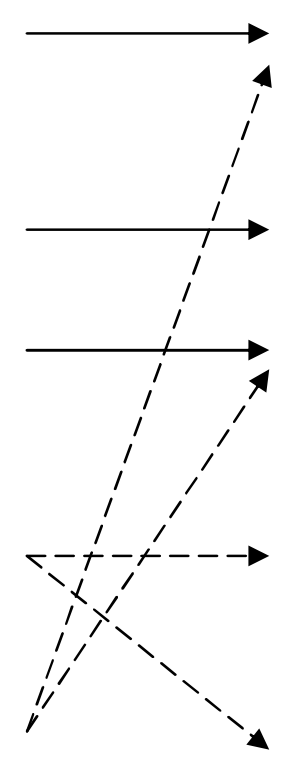

1 A broad and heightened sense of responsibility develops early in life, which is encouraged by significant figures.

2) Rigid codes of conduct.

3) Shielded from responsibility

OQA: Origins Questionnaire for Adolescents 
Figure 2

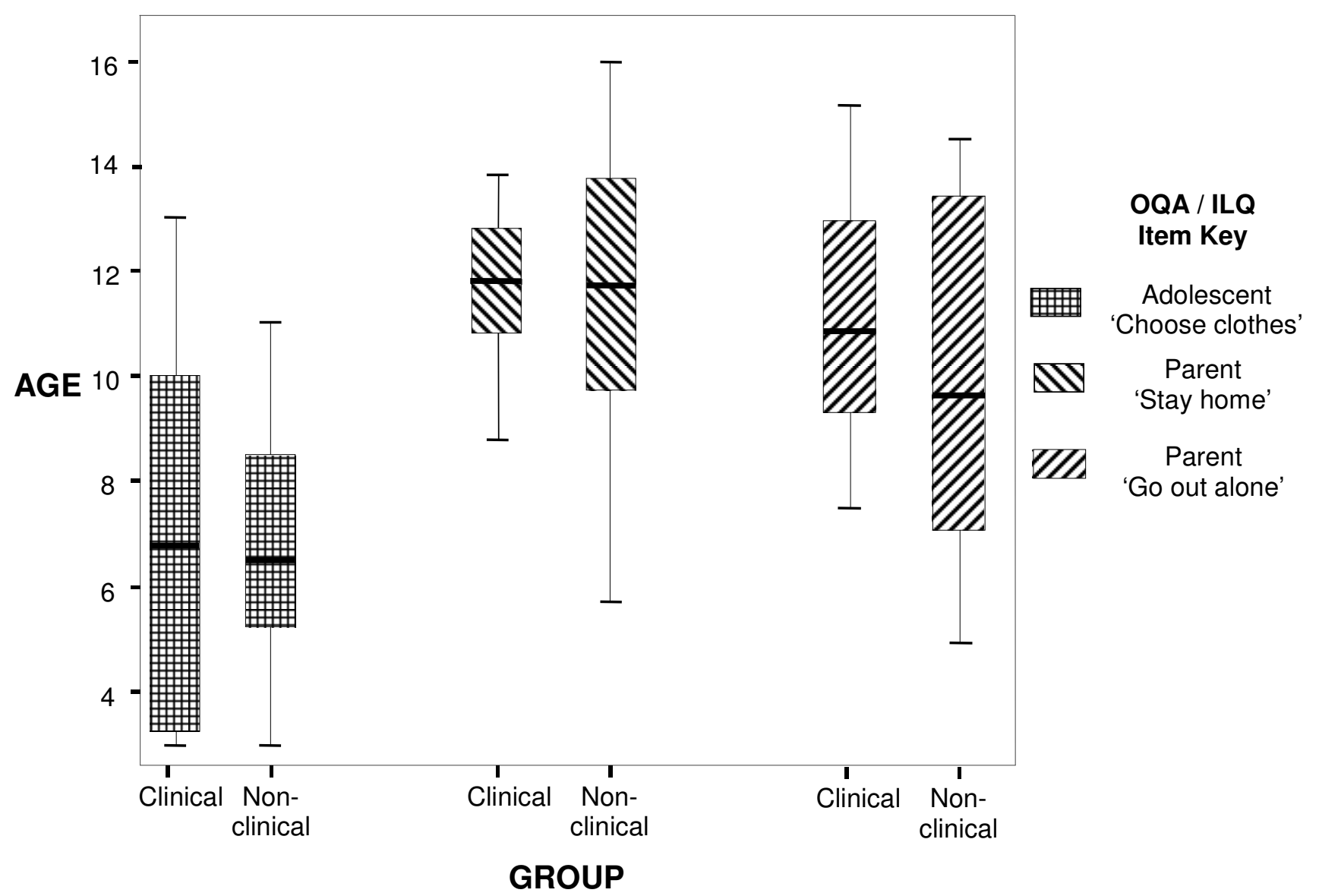

